\title{
Free Rhodium (II) citrate and rhodium (II) citrate magnetic carriers as potential strategies for breast cancer therapy
}

Marcella LB Carneiro ${ }^{1 *+}$, Eloiza S Nunes ${ }^{2}$, Raphael CA Peixoto ${ }^{1}$, Ricardo GS Oliveira', Luiza HM Lourenço ${ }^{1}$, Izabel CR da Silva ${ }^{1}$, Andreza R Simioni ${ }^{3}$, Antônio C Tedesco ${ }^{3}$, Aparecido R de Souza², Zulmira GM Lacava ${ }^{1}$ and Sônia N Báo ${ }^{1}$

\begin{abstract}
Background: Rhodium (II) citrate $\left(\mathrm{Rh}_{2}\left(\mathrm{H}_{2} \mathrm{Cit}\right)_{4}\right)$ has significant antitumor, cytotoxic, and cytostatic activity on Ehrlich ascite tumor. Although toxic to normal cells, its lower toxicity when compared to carboxylate analogues of rhodium (II) indicates $\mathrm{Rh}_{2}\left(\mathrm{H}_{2} \mathrm{Cit}\right)_{4}$ as a promising agent for chemotherapy. Nevertheless, few studies have been performed to explore this potential. Superparamagnetic particles of iron oxide (SPIOs) represent an attractive platform as carriers in drug delivery systems (DDS) because they can present greater specificity to tumor cells than normal cells. Thus, the association between $\mathrm{Rh}_{2}\left(\mathrm{H}_{2} \mathrm{Cit}\right)_{4}$ and SPIOs can represent a strategy to enhance the former's therapeutic action. In this work, we report the cytotoxicity of free rhodium (II) citrate $\left(\mathrm{Rh}_{2}\left(\mathrm{H}_{2} \mathrm{Cit}\right)_{4}\right)$ and rhodium (II) citrate-loaded maghemite nanoparticles or magnetoliposomes, used as drug delivery systems, on both normal and carcinoma breast cell cultures.
\end{abstract}

Results: Treatment with free $\mathrm{Rh}_{2}\left(\mathrm{H}_{2} \mathrm{Cit}\right)_{4}$ induced cytotoxicity that was dependent on dose, time, and cell line. The $I_{50}$ values showed that this effect was more intense on breast normal cells (MCF-10A) than on breast carcinoma cells (MCF-7 and 4T1). However, the treatment with $50 \mu \mathrm{M} \mathrm{Rh}{ }_{2}\left(\mathrm{H}_{2} \mathrm{Cit}\right)_{4}$-loaded maghemite nanoparticles (Magh- $\mathrm{Rh}_{2}\left(\mathrm{H}_{2} \mathrm{Cit}\right)_{4}$ ) and $\mathrm{Rh}_{2}\left(\mathrm{H}_{2} \mathrm{Cit}\right)_{4}$-loaded magnetoliposomes (Lip-Magh- $\left.\mathrm{Rh}_{2}\left(\mathrm{H}_{2} \mathrm{Cit}\right)_{4}\right)$ induced a higher cytotoxicity on MCF-7 and $4 \mathrm{~T} 1$ than on MCF-10A $(p<0.05)$. These treatments enhanced cytotoxicity up to 4.6 times. These cytotoxic effects, induced by free $\mathrm{Rh}_{2}\left(\mathrm{H}_{2} \mathrm{cit}\right)_{4}$, were evidenced by morphological alterations such as nuclear fragmentation, membrane blebbing and phosphatidylserine exposure, reduction of actin filaments, mitochondrial condensation and an increase in number of vacuoles, suggesting that $\mathrm{Rh}_{2}\left(\mathrm{H}_{2} \mathrm{Cit}\right)_{4}$ induces cell death by apoptosis.

Conclusions: The treatment with rhodium (II) citrate-loaded maghemite nanoparticles and magnetoliposomes induced more specific cytotoxicity on breast carcinoma cells than on breast normal cells, which is the opposite of the results observed with free $\mathrm{Rh}_{2}\left(\mathrm{H}_{2} \mathrm{Cit}\right)_{4}$ treatment. Thus, magnetic nanoparticles represent an attractive platform as carriers in $\mathrm{Rh}_{2}\left(\mathrm{H}_{2} \mathrm{cit}\right)_{4}$ delivery systems, since they can act preferentially in tumor cells. Therefore, these nanopaticulate systems may be explored as a potential tool for chemotherapy drug development.

\footnotetext{
* Correspondence: marbretas@gmail.com

+ Contributed equally

'Instituto de Ciências Biológicas, Universidade de Brasilia (UnB), Brazil. 70.919-

970

Full list of author information is available at the end of the article
} 


\section{Background}

Breast carcinoma represents the major cause of death among women worldwide. More than 410,000 deaths are estimated to occur every year, due to its high metastatic capability [1]. This fact demands a continuous development of drugs that may effectively treat breast cancer patients. In point of fact, there is a wide field of research concerning antitumor activity of metal complexes such as platinum [2], ruthenium [3], and rhodium [4]. Among these, rhodium carboxylates are known for their capacity to unpair DNA bases and therefore inhibit DNA synthesis. Their antitumor effect has already been studied on Ehrlich ascites tumor, P388 lymphocytic leukemia, oral carcinoma, L1210 and B16 melanoma, MCa mammary carcinoma and Lewis lung carcinoma [4-6].

The structure of rhodium (II) citrate $\left(\mathrm{Rh}_{2}\left(\mathrm{H}_{2} \mathrm{cit}\right)_{4}\right)$, a rhodium carboxylate, is consistent with the familiar dimeric "lantern" structure with bridging carboxylates and a metal-metal bond (Scheme 1). Interestingly, $\mathrm{Rh}_{2}$ $\left(\mathrm{H}_{2} \mathrm{Cit}\right)_{4}$ has significant antitumor, cytotoxic, and cytostatic activity on Ehrlich ascites tumor [7]. Although toxic to normal cells, its lower toxicity when compared to carboxylate analogues of rhodium (II) indicates $\mathrm{Rh}_{2}$ $\left(\mathrm{H}_{2} \mathrm{Cit}\right)_{4}$ as a promising agent for chemotherapy [4]. Nevertheless, few studies have been performed to explore this potential.

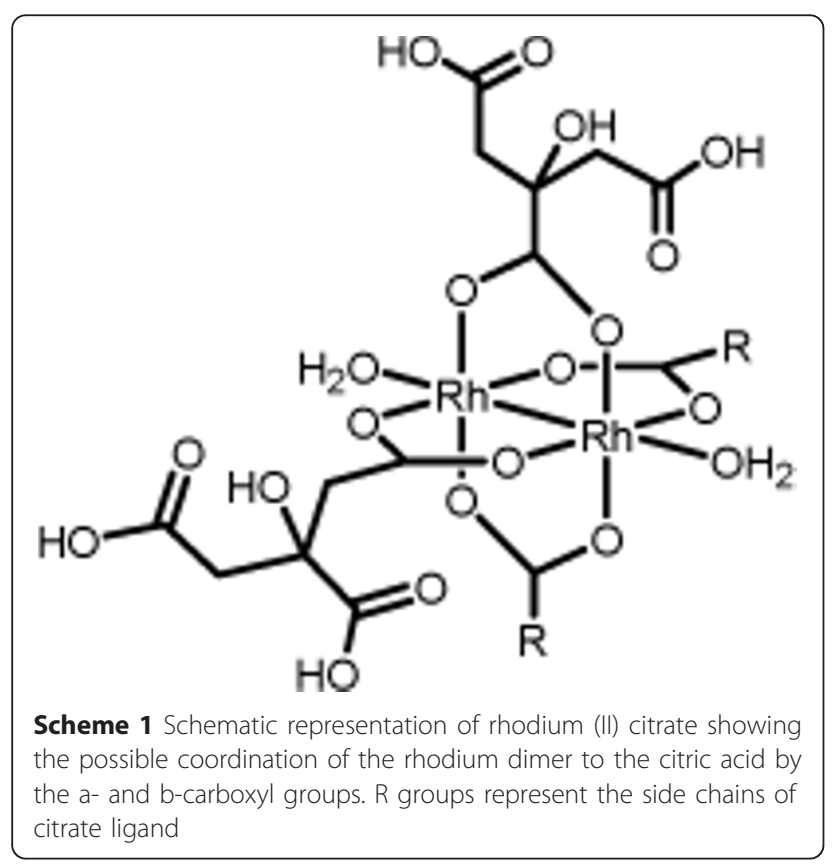

$\mathrm{Rh}_{2}\left(\mathrm{H}_{2} \mathrm{cit}\right)_{4}$ presents uncoordinated functional groups $(-\mathrm{COOH}$ and $-\mathrm{OH})$ in its structure. These groups may establish physical or chemical interactions when used in reaction steps with specific molecules or surfaces. Further, these functional groups are chemically similar to bioactive molecules that have been used to functionalize nanostructure materials, such as magnetic nanoparticles, leading to stable colloidal suspensions with excellent biocompatibility and stability [8].

Superparamagnetic particles of iron oxide with appropriate surface functionalization/encapsulation, presented as magnetic fluids or magnetoliposomes, represent an attractive platform as carriers in drug delivery systems (DDS) because they can act specifically in tumor cells [9]. The success of magnetic nanoparticles is mainly due to their high surface area, capacity to pass through the tumor cell membrane and retention to the tumor tissue [10]. In this context, the association between $\mathrm{Rh}_{2}\left(\mathrm{H}_{2} \mathrm{cit}\right)_{4}$ and magnetic nanoparticles, in magnetic fluids or in magnetoliposomes, may work as target-specific drug delivery systems, representing a strategy for enhancement of the therapeutic action of $\mathrm{Rh}_{2}\left(\mathrm{H}_{2} \mathrm{cit}\right)_{4}$ without affecting normal cells.

Some anticancer drugs associated with magnetic nanoparticles such as doxorubicin [11], methotrexate [12], tamoxifen [13], paclitaxel [14], and cisplatin [15] have high potential for chemotherapy. Among the magnetic particles, maghemite $\left(\gamma-\mathrm{Fe}_{2} \mathrm{O}_{3}\right)$ is suitable for clinical applications due to its magnetic properties and low toxicity [16]. In this work, we investigated the cytotoxicity induced by (1) free $\mathrm{Rh}_{2}\left(\mathrm{H}_{2} \mathrm{cit}\right)_{4}$, (2) $\mathrm{Rh}_{2}\left(\mathrm{H}_{2} \text { cit }\right)_{4}$-loaded maghemite nanoparticles (Magh- $\left.\mathrm{Rh}_{2}\left(\mathrm{H}_{2} \mathrm{cit}\right)_{4}\right)$ and (3) $\mathrm{Rh}_{2}\left(\mathrm{H}_{2} \mathrm{cit}\right)_{4}$-loaded magnetoliposomes (Lip-Magh- $\mathrm{Rh}_{2}$ $\left.\left(\mathrm{H}_{2} \mathrm{Cit}\right)_{4}\right)$ on both normal and carcinoma breast cell cultures.

The association of $\mathrm{Rh}_{2}\left(\mathrm{H}_{2} \mathrm{cit}\right)_{4}$ to magnetic nanoparticles induced specific cytotoxic effect in carcinoma cells. Therefore, we suggest that Magh- $\mathrm{Rh}_{2}\left(\mathrm{H}_{2} \mathrm{cit}\right)_{4}$ and LipMagh- $\mathrm{Rh}_{2}\left(\mathrm{H}_{2} \mathrm{cit}\right)_{4}$ may be explored as potential drugs for chemotherapy.

\section{Results}

\section{- Characterization of rhodium (II) citrate}

Elemental analyses of rhodium (II) citrate sample are consistent with the molecular formula $\left[\mathrm{Rh}_{2}\left(\mathrm{C}_{6} \mathrm{H}_{7} \mathrm{O}_{7}\right)_{4}\right.$ $\left(\mathrm{H}_{2} \mathrm{O}\right)_{2}$ ] and suggest, in solid state, the presence of two water molecules in axial position. Thermal studies of the complex showed that the temperature ranged from 25 to $140^{\circ} \mathrm{C}$, with an estimated mass loss $4.1 \%$ (calculated mass loss $=3.6 \%$ ), which can be accounted for by the loss of the two water molecules. The ESI-MS spectrum of $\left[\mathrm{Rh}_{2}\left(\mathrm{C}_{6} \mathrm{H}_{7} \mathrm{O}_{7}\right)_{4}+\mathrm{H}\right]^{+}$(Figure 1A) shows prominent peaks at $\mathrm{m} / \mathrm{z}=970.8$, corresponding to $\left[\mathrm{Rh}_{2}\left(\mathrm{C}_{6} \mathrm{H}_{7} \mathrm{O}_{7}\right)_{4}+1 \mathrm{H}\right]^{+}$.

The complex was observed in a ${ }^{13} \mathrm{C}$ NMR spectrum (Figure 1B) where the signals of $\alpha$ - and $\beta$-carboxyl carbon atoms in the complex (195.3 and $192.8 \mathrm{ppm}$, respectively) appear shifted in comparison with those with free ligands (179 and $176.5 \mathrm{ppm}$, respectively). The shift and split of observed $\mathrm{C}-\mathrm{O}$ stretching frequencies 


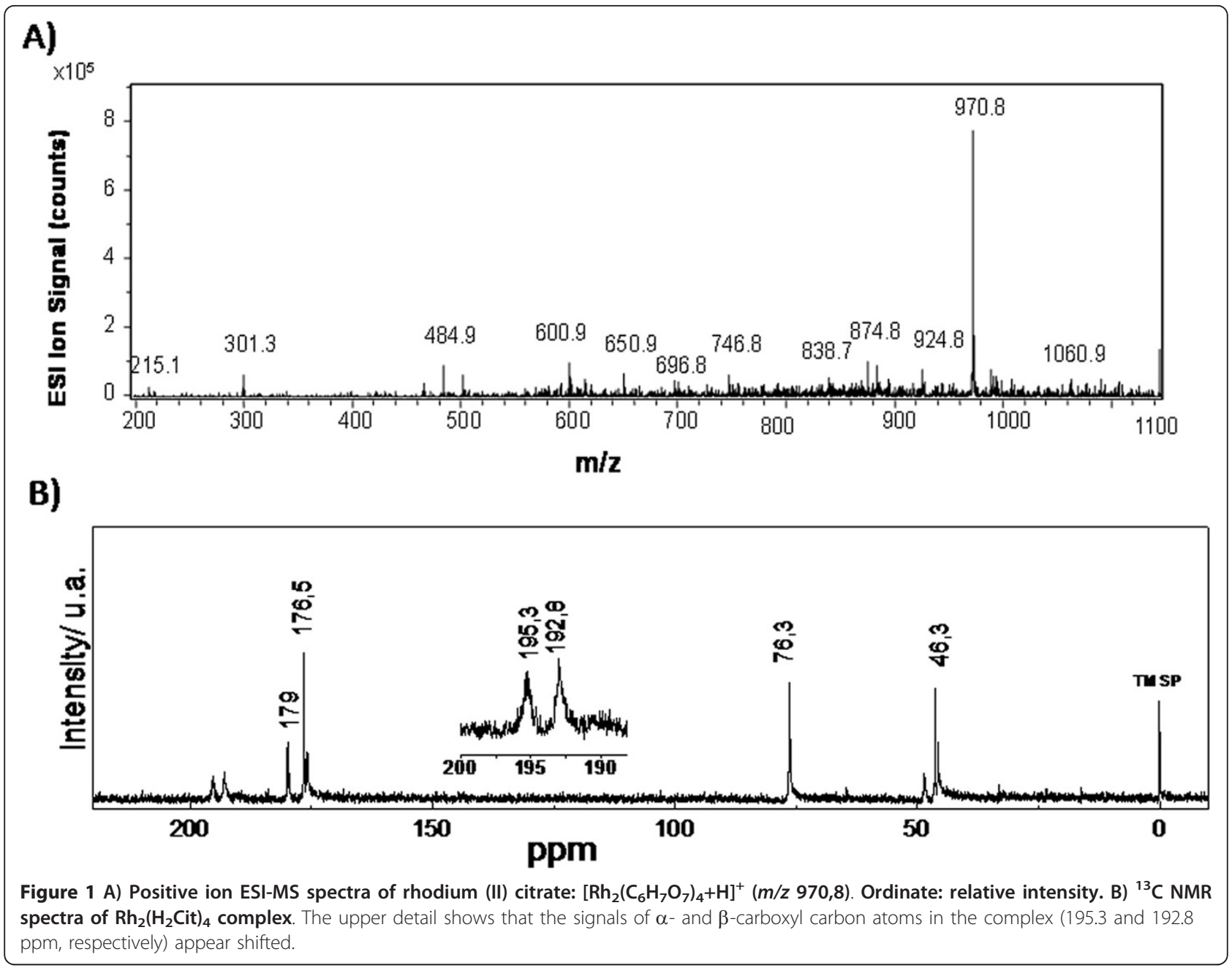

(from 1740 to 1592 and $1412 \mathrm{~cm}^{-1}$ ) of citric acid in infrared spectra has been used to show the coordination of citric acid to rhodium. The value of $\Delta\left(v_{\mathrm{as}} \mathrm{CO}_{2}-v_{\mathrm{s}}\right.$ $\left.\mathrm{CO}_{2}\right)=184 \mathrm{~cm}^{-1}$ observed in the spectrum of rhodium (II) citrate suggests the occurrence of a bridged or chelated bidentate coordination.

The titration of free carboxylic acid groups in the complex provided a ratio of $7.4 \pm 0.4 \mathrm{~mol} \mathrm{H}^{+}$by complex mol, indicating a $8: 1$ stoichiometry predicted by the proposed formula $\mathrm{Rh}_{2}\left(\mathrm{H}_{2} \mathrm{cit}\right)_{4}$.

\section{- Characterization of Magnetic Nanoparticles and Magnetoliposomes}

SPIOs were obtained in the maghemite $\left(\gamma-\mathrm{Fe}_{2} \mathrm{O}_{3}\right)$ phase and presented the characteristic diffraction patterns of inverse spinel structure when compared to reference patterns in the literature [17] for maghemite from the International Center of Diffraction Data [18] (Figure $2 \mathrm{~A})$. The molar ratio of $\mathrm{Fe}^{2+} / \mathrm{Fe}^{3+}$ obtained by elemental analysis was less than 0.015 , revealing an efficient oxidation from magnetite to maghemite phase.
The magnetization curves for bare maghemite (Magh) and surface modified maghemite $\left(\mathrm{Magh}-\mathrm{Rh}_{2}\left(\mathrm{H}_{2} \mathrm{Cit}\right)_{4}\right)$ are shown in Figure 2B. For both samples, the curves indicate superparamagnetic behavior, since no hysteresis was observed $[19,20]$. The saturation of magnetization was $48 \mathrm{emug}^{-1}$ to Magh and $45 \mathrm{emug}^{-1}$ to Magh- $\mathrm{Rh}_{2}\left(\mathrm{H}_{2} \mathrm{cit}\right)_{4}$.

The surface modification of maghemite nanoparticles was evidenced by infrared spectroscopy and zeta potential measurements. The infrared spectra of functionalized nanoparticles (Figure 2C) show intense absorptions in 1630 and $1564 \mathrm{~cm}^{-1}$ assigned to asymmetrical $v_{\mathrm{as}}(\mathrm{COO})$ and symmetrical $v_{\mathrm{s}}(\mathrm{COO})$ stretching modes of carboxylate groups [21]. These bands indicate the chemical adsorption of $\mathrm{Rh}_{2}\left(\mathrm{H}_{2} \mathrm{Cit}\right)_{4}$ molecules onto the oxide surface [22]. In $1724 \mathrm{~cm}^{-1}$, the stretching vibration of carboxylic acid $v(\mathrm{C}=\mathrm{O})$ is observed.

The presence of free acid groups is consistent with obtainment of stable magnetic fluids in physiological $\mathrm{pH}$. The surface Magh- $\mathrm{Rh}_{2}\left(\mathrm{H}_{2} \mathrm{cit}\right)_{4}$ presented a negative zeta potential in a broad range of $\mathrm{pH}$ values, and its magnitude in $\mathrm{pH} 7$ was about $-35 \mathrm{mV}$ (Figure 2D). 

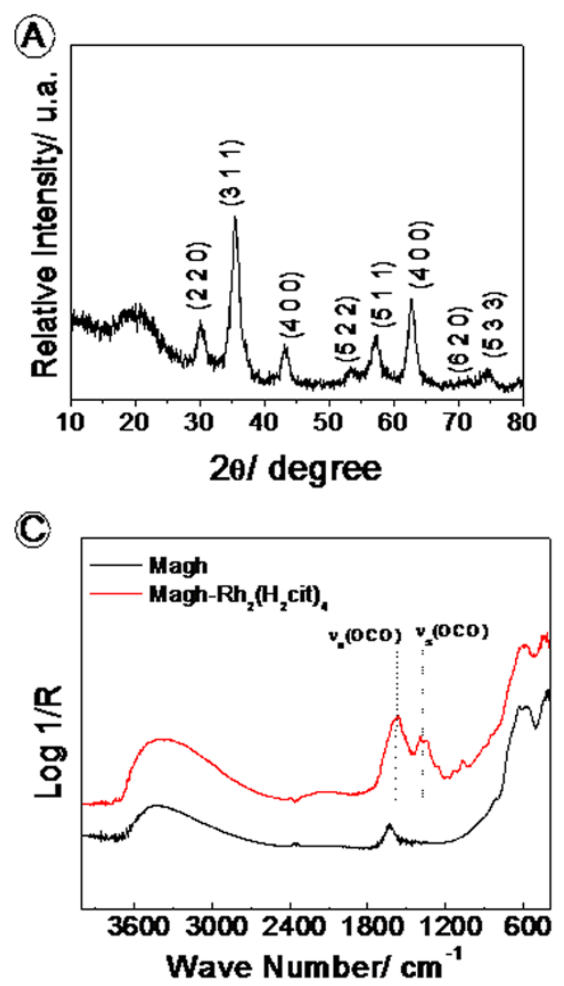
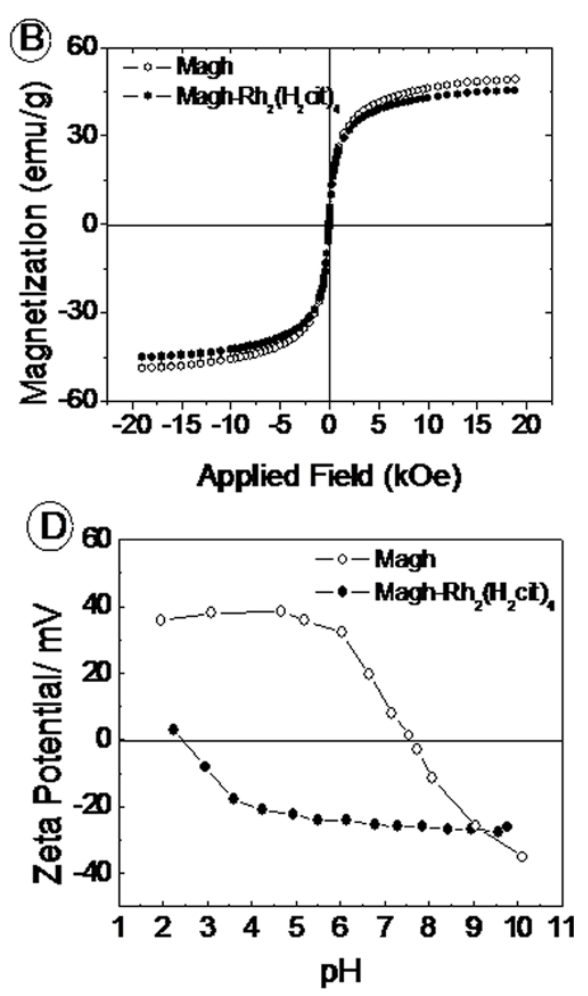

Figure 2 A) Diffraction pattern for sample Magh. B) Magnetization curves at $300 \mathrm{~K}$ for bare: $\circ$ maghemite (Magh), and $\bullet$ modified maghemite $\left(\right.$ Magh- $\left.\mathrm{Rh}_{2}\left(\mathrm{H}_{2} \mathrm{Cit}\right)_{4}\right)$. C) Infrared Spectra for __ Magh and - - Magh-Rh $\left.{ }_{2}\left(\mathrm{H}_{2} \mathrm{Cit}\right)_{4} ; \mathrm{D}\right)$ Zeta potential versus pH curves for $\square \circ \square \mathrm{Magh}$, and $\square \bullet \square \mathrm{Magh}-\mathrm{Rh}_{2}\left(\mathrm{H}_{2} \mathrm{Cit}\right)_{4}$.

The complex and iron oxide content in the sample Magh- $\mathrm{Rh}_{2}\left(\mathrm{H}_{2} \mathrm{cit}\right)_{4}$ were $1.4 \mathrm{mmolL}^{-1}$ and $0.33 \mathrm{molL}^{-1}$, respectively.

The magnetoliposome size presented an average measurement of $101.8 \pm 0.1 \mathrm{~nm}$, with polydispersion index lower than 0.22 , which corresponded to $98 \%$ of the Gaussian distribution (Figure 3).

TEM micrographs revealed that the maghemite nanoparticles used $\left(\right.$ Magh- $\left.\mathrm{Rh}_{2}\left(\mathrm{H}_{2} \mathrm{cit}\right)_{4}\right)$ have a spherical shape (Figure 4A) and a modal diameter of $7.85 \mathrm{~nm}$ $(\mathrm{SD}=2.10)$ (Figure 4B). In contrast, samples of Lip-

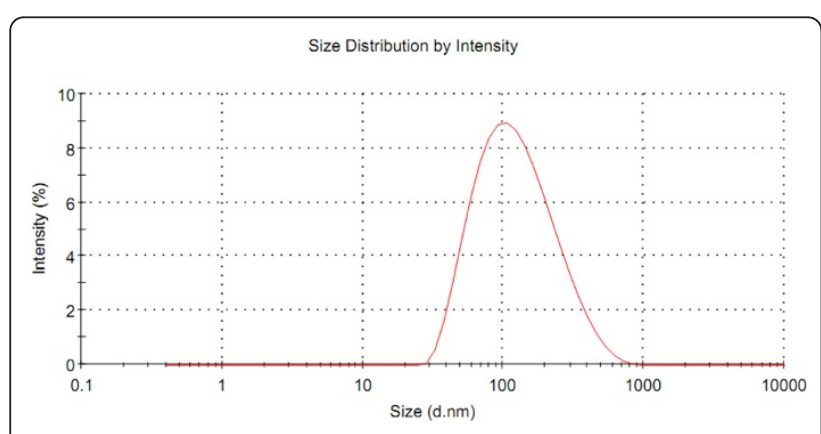

Figure 3 Size analysis of the magnetoliposomes $\left(1.96 \times 10^{15}\right.$ iron particles $/ \mathrm{mL}$ ) by laser light scattering.
Magh- $\mathrm{Rh}_{2}\left(\mathrm{H}_{2} \mathrm{Cit}\right)_{4}$ have a rounded shape (Figure $4 \mathrm{C}$ ) and a modal diameter of $28.19 \mathrm{~nm}(\mathrm{SD}=6.17)$ (Figure 4D). Different sized nanoparticles were also observed in the samples, demonstrating their polydispersed distribution.

\section{- Cytotoxicity of free rhodium (II) citrate}

The distribution of cell viability according to the treatment, time, and the evaluated cell line after incubation with free rhodium (II) citrate $\left(\mathrm{Rh}_{2}\left(\mathrm{H}_{2} \mathrm{cit}\right)_{4}\right)$ is shown in Table 1. A significant difference in the viability of the cells with and without $\mathrm{Rh}_{2}\left(\mathrm{H}_{2} \mathrm{cit}\right)_{4}$ treatment was observed, independently of the cell line and the duration of treatment $(\mathrm{p}<0.05)$. We did not observe cytotoxicity at doses lower than $50 \mu \mathrm{M} \mathrm{Rh}{ }_{2}\left(\mathrm{H}_{2} \mathrm{Cit}\right)_{4}$ (data not shown). All cell lines presented similar cytotoxic effect of $50 \mu \mathrm{M} \mathrm{Rh}{ }_{2}\left(\mathrm{H}_{2} \text { cit }\right)_{4}$ after 24,48 , and $72 \mathrm{~h}$ treatments. However, at doses higher than $200 \mu \mathrm{M}$, higher cytotoxicity was observed on breast normal cell line (MCF-10A) than on breast carcinoma cell lines (MCF-7 and 4T1). In general, the cytotoxic effect of $\mathrm{Rh}_{2}\left(\mathrm{H}_{2} \mathrm{Cit}\right)_{4}$ was higher after $72 \mathrm{~h}$ and after treatments with 500 and $600 \mu \mathrm{M}$ doses $(\mathrm{p}<0.05)$. Thus, $\mathrm{Rh}_{2}\left(\mathrm{H}_{2} \mathrm{cit}\right)_{4}$ induced a dose and time-dependent viability reduction on the investigated cell lines. 


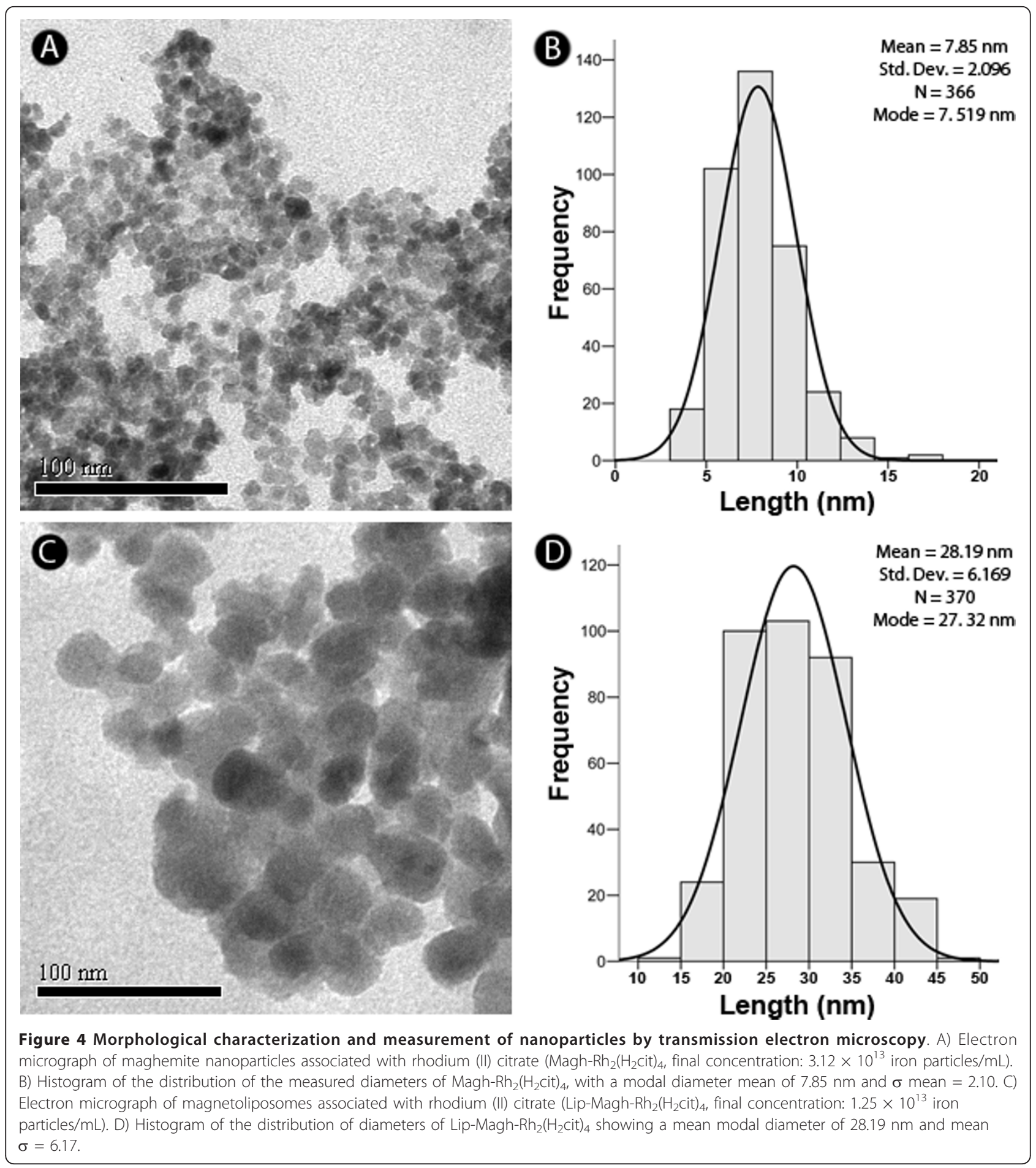

Paclitaxel $(50 \mu \mathrm{M})$, used as positive control, induced a more intense cytotoxic effect after $72 \mathrm{~h}$ in the three cell lines than $\mathrm{Rh}_{2}\left(\mathrm{H}_{2} \mathrm{cit}\right)_{4}$. Treatments with DMSO caused no significant cytotoxicity to the three cell lines studied after 24 and $48 \mathrm{~h}$ treatments. Nevertheless, after $72 \mathrm{~h}$, DMSO demonstrated a higher cytotoxicity to $4 \mathrm{~T} 1$ and
MCF-10A cells lines than to MCF-7 line. Since the cells studied showed sensitivity to paclitaxel our experimental models were validated (Table 1).

The $\mathrm{IC}_{50}$ values of the treatments with $\mathrm{Rh}_{2}\left(\mathrm{H}_{2} \mathrm{cit}\right)_{4}$ in MCF-7, 4T1, and MCF-10A cells are shown in Table 2. The results confirmed that the cytotoxicity of the 
Table 1 Distribution of cell viability percentage according to the treatment, cell line and exposure time

\begin{tabular}{|c|c|c|c|c|c|c|c|}
\hline Treatment & Cell line & $24 \mathrm{~h}$ & & $48 \mathrm{~h}$ & & $72 \mathrm{~h}$ & \\
\hline \multirow[t]{3}{*}{0 (control) } & MCF-7 & $100.00 \pm 1.50$ & $A^{*} ; a^{\#}$ & $99.94 \pm 1.95$ & $A ; a$ & $100.00 \pm 1.06$ & $A ; a$ \\
\hline & $4 \mathrm{~T} 1$ & $100.00 \pm 1.21$ & $A ; a$ & $100.00 \pm 1.46$ & $A ; a$ & $100.00 \pm 1.34$ & $A ; a$ \\
\hline & MCF-10A & $100.00 \pm 3.30$ & $A ; a$ & $100.00 \pm 1.05$ & $A ; a$ & $100.00 \pm 0.92$ & $A ; a$ \\
\hline \multirow[t]{3}{*}{$\mathrm{Rh}_{2}\left(\mathrm{H}_{2} \mathrm{cit}\right)_{4} 50 \mu \mathrm{M}$} & MCF-7 & $94.96 \pm 2.44$ & $A ; a$ & $97.48 \pm 2.84$ & $A ; a$ & $81.19 \pm 2.30$ & $\mathrm{~B} ; \mathrm{a}$ \\
\hline & $4 \mathrm{~T} 1$ & $90.31 \pm 1.38$ & $A ; a$ & $87.79 \pm 2.63$ & A.B; a & $81.42 \pm 2.56$ & $\mathrm{~B} ; \mathrm{a}$ \\
\hline & MCF-10A & $97.75 \pm 3.77$ & $A ; a$ & $97.82 \pm 1.40$ & $A ; a$ & $84.30 \pm 2.55$ & $\mathrm{~B} ; \mathrm{a}$ \\
\hline \multirow[t]{3}{*}{$\mathrm{Rh}_{2}\left(\mathrm{H}_{2} \mathrm{cit}\right)_{4} 200 \mu \mathrm{M}$} & MCF-7 & $89.28 \pm 2.60$ & $A ; a$ & $81.64 \pm 2.38$ & $A ; a$ & $70.13 \pm 2.58$ & $\mathrm{~B} ; \mathrm{a}$ \\
\hline & $4 \mathrm{~T} 1$ & $79.13 \pm 1.44$ & $A ; b$ & $73.42 \pm 2.17$ & A.B; a & $68.12 \pm 3.64$ & $\mathrm{~B} ; \mathrm{a}$ \\
\hline & MCF-10A & $61.82 \pm 6.54$ & $A ; b$ & $44.19 \pm 1.60$ & $B ; b$ & $30.43 \pm 2.69$ & $C_{;} ; b$ \\
\hline \multirow[t]{3}{*}{$\mathrm{Rh}_{2}\left(\mathrm{H}_{2} \mathrm{cit}\right)_{4} 300 \mu \mathrm{M}$} & MCF-7 & $85.33 \pm 2.14$ & $A ; a$ & $73.77 \pm 2.58$ & $B ; a$ & $54.14 \pm 2.47$ & $\mathrm{C} ; \mathrm{a}$ \\
\hline & $4 \mathrm{~T} 1$ & $73.95 \pm 2.54$ & $A ; a$ & $61.77 \pm 1.47$ & $B ; b$ & $47.79 \pm 4.11$ & $C_{i} \mathrm{a}$ \\
\hline & MCF-10A & $39.41 \pm 7.47$ & $A ; b$ & $23.81 \pm 0.74$ & $B ; C$ & $12.78 \pm 0.92$ & $c ; b$ \\
\hline \multirow[t]{3}{*}{$\mathrm{Rh}_{2}\left(\mathrm{H}_{2} \mathrm{cit}\right)_{4} 500 \mu \mathrm{M}$} & MCF-7 & $50.08 \pm 2.49$ & $A ; a$ & $25.29 \pm 3.46$ & B.C; a & $30.39 \pm 3.47$ & $\mathrm{C} ; \mathrm{a}$ \\
\hline & $4 \mathrm{~T} 1$ & $46.14 \pm 3.49$ & $A ; a$ & $30.66 \pm 1.22$ & $\mathrm{~B} ; \mathrm{a}$ & $26.07 \pm 2.75$ & $\mathrm{~B} ; \mathrm{a}$ \\
\hline & MCF-10A & $25.85 \pm 6.46$ & $A ; b$ & $11.62 \pm 1.17$ & A.B; b & $5.46 \pm 0.46$ & $c_{;} b$ \\
\hline \multirow[t]{3}{*}{$\mathrm{Rh}_{2}\left(\mathrm{H}_{2} \mathrm{cit}\right)_{4} 600 \mu \mathrm{M}$} & MCF-7 & $28.71 \pm 3.90$ & $A ; a$ & $16.86 \pm 1.77$ & $\mathrm{~B} ; \mathrm{a}$ & $12.16 \pm 1.93$ & $\mathrm{~B} ; \mathrm{a}$ \\
\hline & $4 \mathrm{~T} 1$ & $29.87 \pm 3.67$ & $A ; a$ & $15.86 \pm 0.57$ & $B ; a$ & $9.97 \pm 1.49$ & $\mathrm{~B} ; \mathrm{a}$ \\
\hline & MCF-10A & $13.34 \pm 2.43$ & $A ; b$ & $10.26 \pm 1.27$ & $A ; b$ & $4.76 \pm 0.39$ & $B ; b$ \\
\hline \multirow[t]{3}{*}{ DMSO $(0.85 \%)$} & MCF-7 & $90.51 \pm 5.9$ & $A ; a$ & $90.93 \pm 1.7$ & $A ; a$ & $96.4 \pm 1.4$ & $A ; a$ \\
\hline & $4 \mathrm{~T} 1$ & $106.2 \pm 1.3$ & $A ; b$ & $100.6 \pm 2.97$ & $A ; a$ & $43.07 \pm 8.2$ & $\mathrm{~B} ; \mathrm{b}$ \\
\hline & MCF-10A & $148.1 \pm 6.8$ & $A ; C$ & $82.45 \pm 2.3$ & $\mathrm{~B} ; \mathrm{a}$ & $63.35 \pm 2.2$ & $C_{i} \mathrm{C}$ \\
\hline \multirow[t]{3}{*}{ Paclitaxel $50 \mu \mathrm{M}$} & MCF-7 & $70.07 \pm 0.4$ & $A ; a$ & $55.93 \pm 1.6$ & B; a & $18.92 \pm 4.3$ & $\mathrm{C}_{i} \mathrm{a}$ \\
\hline & $4 \mathrm{~T} 1$ & $68.31 \pm 1.2$ & $A ; a$ & $30.12 \pm 0.7$ & $B ; b$ & $21.51 \pm 1.4$ & $C_{i} \mathrm{a}$ \\
\hline & MCF-10A & $80.17 \pm 6.7$ & $A ; C$ & $33.52 \pm 1.09$ & $B ; b$ & $20.95 \pm 1.1$ & $C_{i} \mathrm{a}$ \\
\hline
\end{tabular}

The data represent the mean \pm SE (mean standard error) of three independent experiments in triplicates. ${ }^{*}$ Different capital letters denote statistical difference between viability in the different times (rows) for a given cell line (breast cancer cells MCF-7. 4T1 or normal cells MCF-10A) under the same treatment ( $p<0.05$ ). \# Different tiny letters indicate mean statistical difference between the viability of different cell lines (columns) for a given time (24. 48 or 72 hours) ( $p<0.05$ ).

treatment with the complex is dependent on dose, time, and cell line. The $\mathrm{IC}_{50}$ values for human carcinoma (MCF-7) and mouse carcinoma (4T1) cell lines were relatively similar. Likewise, normal cell lines (MCF-10A) were more sensitive to treatment with $\mathrm{Rh}_{2}\left(\mathrm{H}_{2} \mathrm{cit}\right)_{4}$ (Table 2).

\section{- Analysis of morphological and structural alterations on MCF-7 and 4T1 cell lines}

MCF-7 cells have predominantly fusiform morphology (Figure 5A), while $4 \mathrm{~T} 1$ cells presented both spindle and rounded cells forming clusters, characteristic of this these types of tumor cells (Figure 6A). Nevertheless, both MCF-7 and 4T1 cells became more rounded and with blebbing after treatment with $500 \mu \mathrm{M} \mathrm{Rh}{ }_{2}\left(\mathrm{H}_{2} \mathrm{cit}\right)_{4}$ for $48 \mathrm{~h}$. After this treatment smaller confluence and reduced cell size were also observed when $4 \mathrm{~T} 1$ and MCF-7 control cells were compared. Furthermore, this effect was more pronounced in the 4T1 cell line (Figure $5 \mathrm{~A}, \mathrm{~B}$ and $6 \mathrm{~A}, \mathrm{~B})$. No morphological alterations were observed in MCF-7 and 4T1 untreated cells (control), according to the images taken by the phase contrast microscope (Figure 5A and 6A).

Ultrastructural details of MCF-7 and 4T1 cell morphology, after treatment with $500 \mu \mathrm{M} \mathrm{Rh}{ }_{2}\left(\mathrm{H}_{2} \mathrm{cit}\right)_{4}$, are shown in Figure 5D, F and 6D, F, respectively. After this treatment, several morphological alterations were observed, such as the presence of blebbing, the

Table 2 Distribution of the IC 50 values and their respective confidence intervals (95\%) in MCF-7, 4T1, and MCF-10A cell lines after treatment with free rhodium (II) citrate $\left(\mathrm{Rh}_{\mathbf{2}}\left(\mathrm{H}_{\mathbf{2}} \mathrm{cit}\right)_{4}\right)$

\begin{tabular}{|c|c|c|c|c|c|c|}
\hline \multirow{3}{*}{$\frac{\text { Cell lines }}{\text { MCF-7 }}$} & \multicolumn{6}{|c|}{$\mathrm{IC}_{50}$ (IC 95\%) } \\
\hline & \multicolumn{2}{|c|}{24 hours } & \multicolumn{2}{|c|}{48 hours } & \multicolumn{2}{|c|}{72 hours } \\
\hline & $483 \mu \mathrm{M}$ & $(459,2$ a $507 \mu \mathrm{M})$ & $376 \mu \mathrm{M}$ & $(356,2$ a $396,1 \mu \mathrm{M})$ & $294 \mu \mathrm{M}$ & $(259,9$ a $332,5 \mu \mathrm{M})$ \\
\hline $4 \mathrm{~T} 1$ & $440 \mu \mathrm{M}$ & $(407,3$ a $475 \mu \mathrm{M})$ & $337 \mu \mathrm{M}$ & $(317,3$ а $357,8 \mu \mathrm{M})$ & $271 \mu \mathrm{M}$ & $(241,4$ a $303,9 \mu \mathrm{M})$ \\
\hline MCF-10A & $250 \mu \mathrm{M}$ & $(211,1$ a $295,2 \mu M)$ & $181 \mu \mathrm{M}$ & $(172,3$ a $190,8 \mu \mathrm{M})$ & $123 \mu \mathrm{M}$ & $(114,7$ a $132,7 \mu \mathrm{M})$ \\
\hline
\end{tabular}

These data refers from viability of cells after treatment with $\mathrm{Rh}_{2}\left(\mathrm{H}_{2} \mathrm{cit}\right)_{4}(50-600 \mu \mathrm{M})$ for 24,48 and 72 hours. 

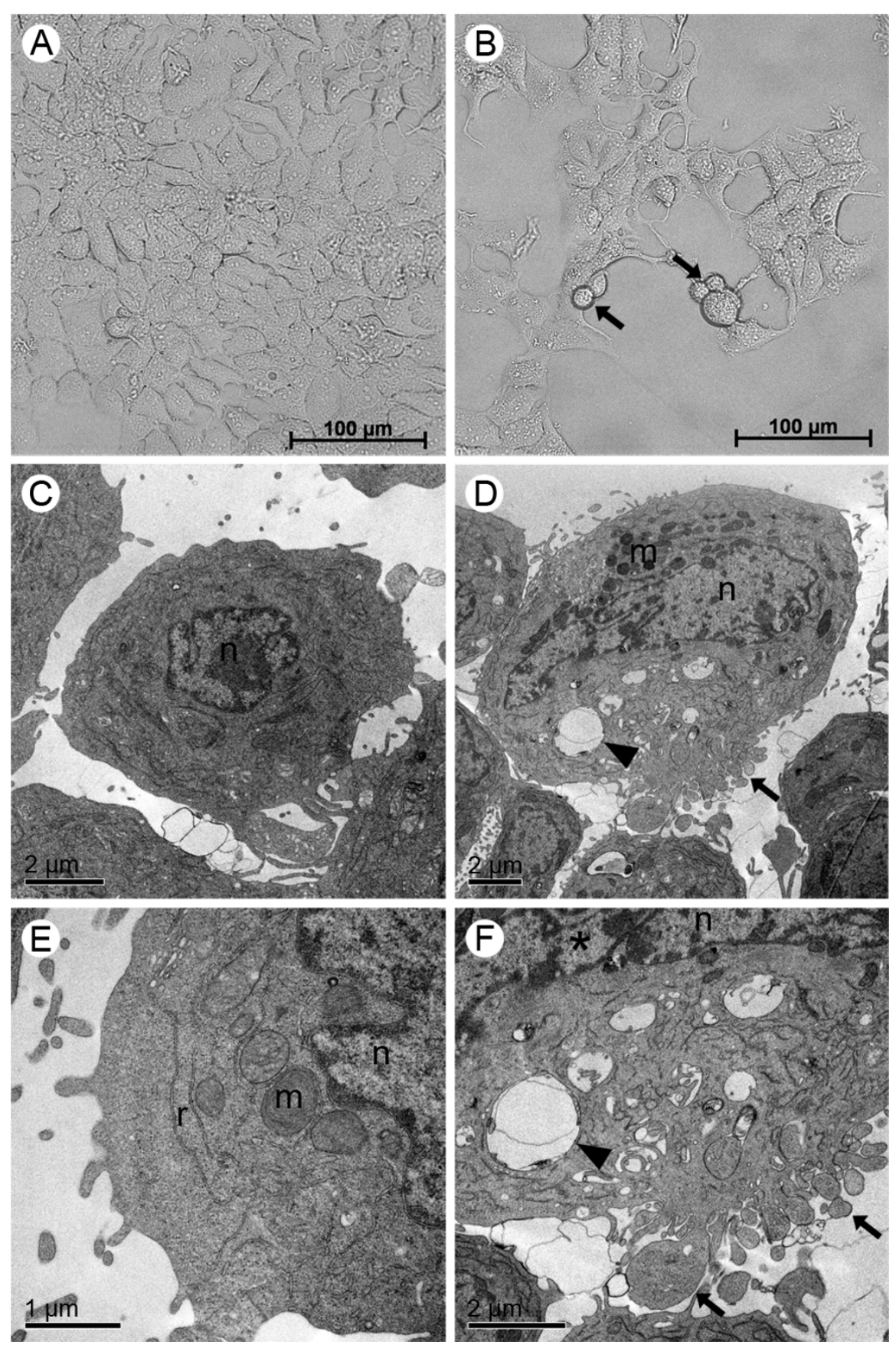

Figure 5 Morphological and structural changes induced by rhodium (II) citrate $\left(\mathrm{Rh}_{2}\left(\mathrm{H}_{2} \mathrm{cit}\right)_{4}\right)$ in $\mathrm{MCF}-7$ breast carcinoma cell line after 48 hours of treatment. Cells were incubated with $500 \mu \mathrm{M} \mathrm{Rh}{ }_{2}\left(\mathrm{H}_{2} \mathrm{Cit}\right)_{4}$ for 48 hours and examined by phase contrast microscopy (A, B) and transmission electron microscopy (C-F). ( $A, C$ and E) control (cells without treatment); (B, D and F) cells treated with $500 \mu M$ of $R h_{2}\left(H_{2} C i t\right)_{4}$. Differences were observed in cell morphology, vacuole amount and mitochondrial condensation between untreated cells $(A, C$ and $E)$ and $R h_{2}$ $\left(\mathrm{H}_{2} \mathrm{Cit}\right)_{4}$ treated cells $(\mathrm{B}, \mathrm{D}$ and $\mathrm{F})$. Legends: blebbing (arrows), vacuoles (arrow heads), nucleus (n), mitochondria (m), condensed chromatin $\left.{ }^{*}\right)$.

segregation of condensed chromatin to nuclear periphery and the remarkable presence of vacuoles and condensed mitochondria when compared to the MCF-7 and $4 \mathrm{~T} 1$ control cells (Figure $5 \mathrm{C}-\mathrm{F}$ and $6 \mathrm{C}-\mathrm{F}$ ), respectively. These morphological changes can be related to the apoptotic events.
- Phosphatidylserine exposition on breast carcinoma cells In Figure 7 the percentage of cells that were positively stained for annexin V-FITC is represented. After $500 \mu \mathrm{M} \mathrm{Rh}{ }_{2}\left(\mathrm{H}_{2} \mathrm{cit}\right)_{4}$ treatment, the annexin- $\mathrm{V}^{+}$cell number (\%) was significantly higher than that of the control in both cell lines $(\mathrm{p}<0.05)$. After this treatment, 

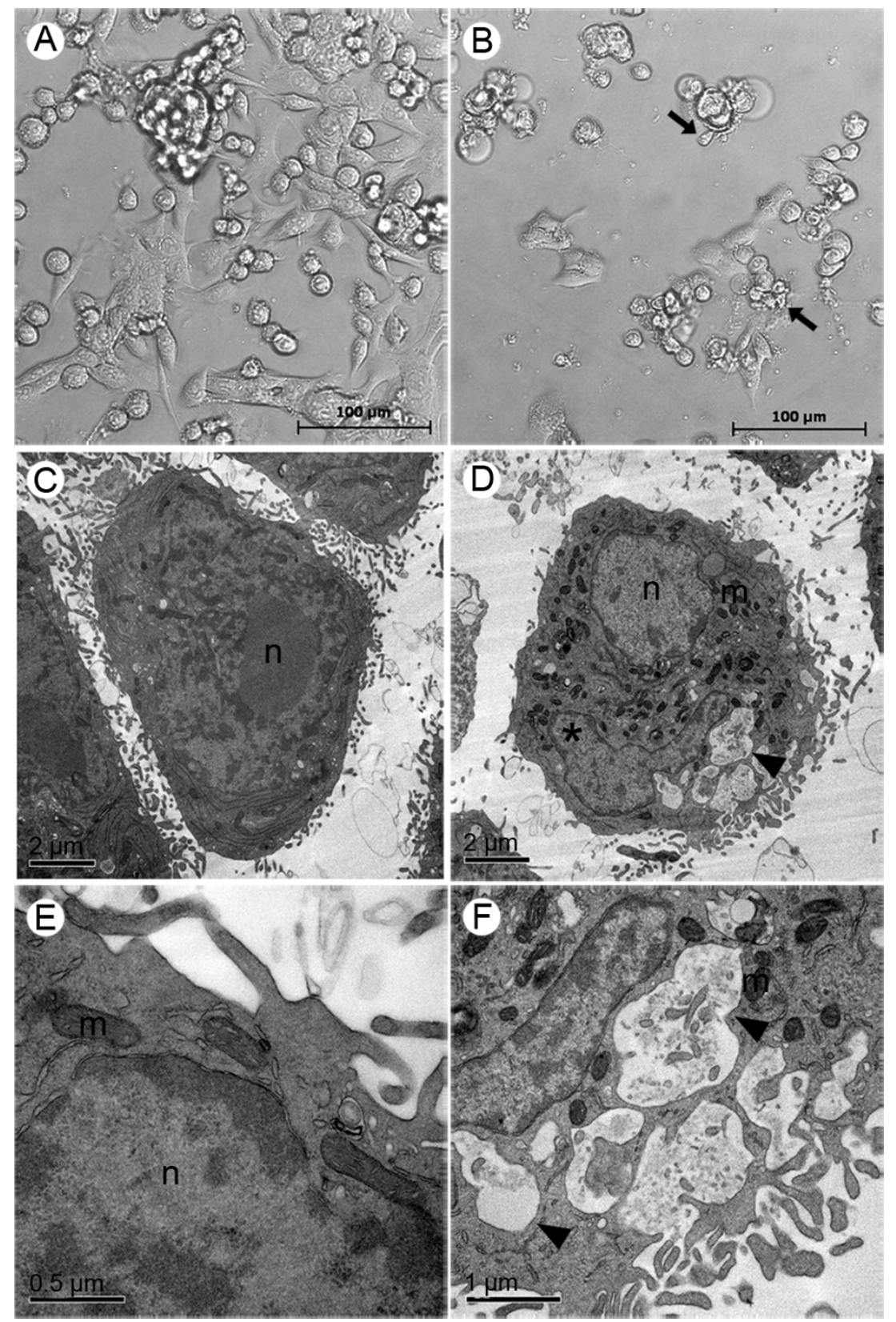

Figure 6 Morphological and structural changes induced by rhodium (II) citrate $\left(\mathrm{Rh}_{2}\left(\mathrm{H}_{2} \mathrm{cit}\right)_{4}\right)$ in $4 \mathrm{~T} 1$ breast carcinoma cell line after 48 hours of treatment. Cells were incubated with $500 \mu \mathrm{M} \mathrm{Rh}{ }_{2}\left(\mathrm{H}_{2} \mathrm{Cit}\right)_{4}$ for 48 hours and examined by phase contrast microscopy (A, B) and transmission electron microscopy (C-F). ( $\mathrm{A}, \mathrm{C}$ and E) control (cells without treatment); ( $\mathrm{B}, \mathrm{D}$ and F) cells treated with $500 \mu \mathrm{M}$ of $\mathrm{Rh}_{2}\left(\mathrm{H}_{2} \mathrm{Cit}\right)_{4}$. Differences were observed in cell morphology, vacuole amount and mitochondrial condensation between untreated cells $(A, C$ and $E)$ and $R h_{2}$ $\left(\mathrm{H}_{2} \mathrm{Cit}\right)_{4}$ treated cells (B, D and F). Legends: blebbing (arrows), vacuoles (arrow heads), nucleus (n), mitochondria (m), condensed chromatin (*).

there was a $25 \%$ and a $38 \%$ increase of annexin- $\mathrm{V}^{+}$cell number in MCF-7 and 4T1, respectively ( $<<0.05$ ), thus revealing that the $4 \mathrm{~T} 1$ cell line was more sensitive to treatment with $\mathrm{Rh}_{2}\left(\mathrm{H}_{2} \mathrm{cit}\right)_{4}(500 \mu \mathrm{M})$. No difference in the percentage of annexin- $\mathrm{V}^{+}$cell number was observed in relation to untreated cells (control) and $50 \mu \mathrm{M} \mathrm{Rh} 2$ $\left(\mathrm{H}_{2} \mathrm{cit}\right)_{4}$ treated cells, in both cell lines $(\mathrm{p}<0.05)$.
- Analysis of nuclear fragmentation and actin alterations MCF-7 cells without treatment (control) showed organized spread actin in the cytoplasm and interactions between surrounding cells through membrane projections supported by actin (Figure 8A). After treatment with $50 \mu \mathrm{M} \mathrm{Rh}{ }_{2}\left(\mathrm{H}_{2} \mathrm{cit}\right)_{4}$, slight nuclear condensation and reduction of actin filaments were observed 


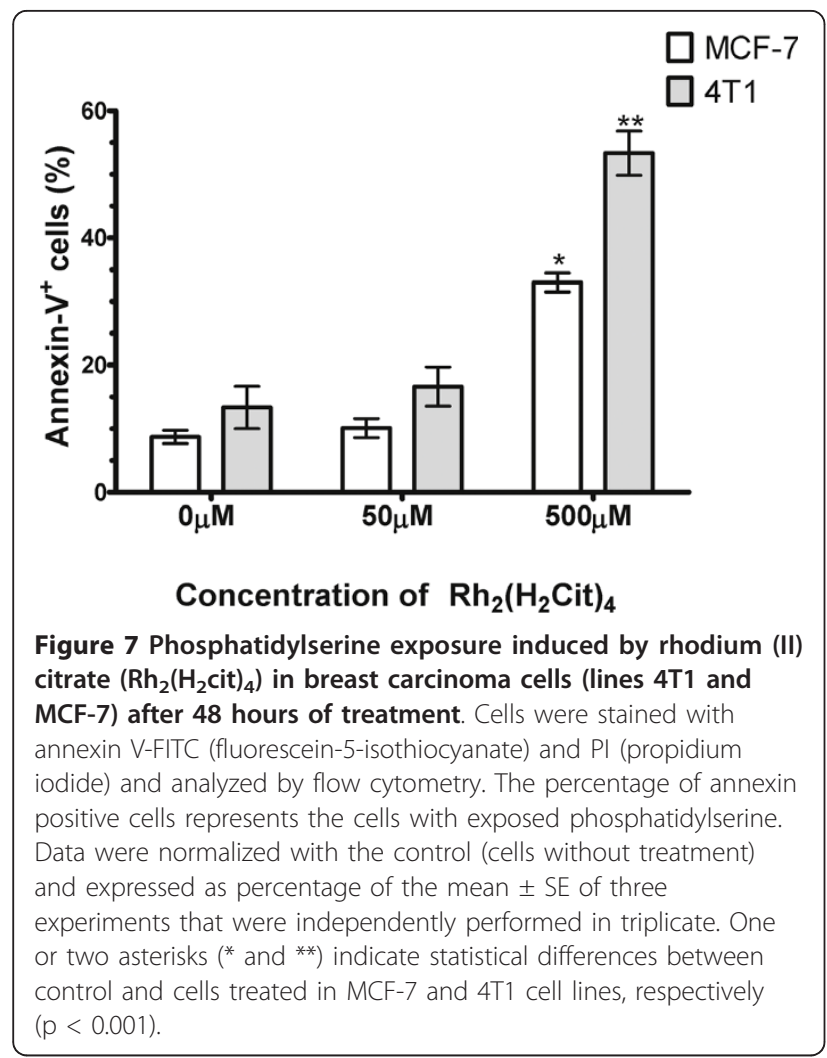

(Figure $8 \mathrm{C}$ ). Nevertheless, a noticeable reduction in actin and increased nuclear condensation were observed after treatment with $500 \mu \mathrm{M}$ (Figure 8E). In general, the cells treated with $\mathrm{Rh}_{2}\left(\mathrm{H}_{2} \mathrm{cit}\right)_{4}$ showed a loss of cytoplasmic projections when compared to the control cells (Figure 8A, C and 8E). Furthermore, the cells treated with paclitaxel $(50 \mu \mathrm{M})$ showed nuclear condensation and fragmentation and a lower amount of actin cytoskeleton, similar to those treated with $\mathrm{Rh}_{2}$ $\left(\mathrm{H}_{2} \mathrm{Cit}\right)_{4}$ (Figure 8G). Phase contrast images were shown to validate DAPI and phalloidin-Alexa Fluor 488 staining for each experimental group (Figure 8B, $\mathrm{D}, \mathrm{F}$ and $8 \mathrm{H}$ ).

\section{- Cytotoxicity of rhodium (II) citrate-loaded magnetic nanoparticles}

MCF-7, 4T1, and MCF-10A cell viabilities were similar after treatment with $50 \mu \mathrm{M}$ of free $\mathrm{Rh}_{2}\left(\mathrm{H}_{2} \mathrm{cit}\right)_{4}$, independent of the treatment duration (Figure 9). Nevertheless, treatment with $50 \mu \mathrm{M} \mathrm{Rh}{ }_{2}\left(\mathrm{H}_{2} \mathrm{Cit}\right)_{4}$-loaded maghemite nanoparticles (Magh- $\mathrm{Rh}_{2}\left(\mathrm{H}_{2} \mathrm{cit}\right)_{4}$ ) and $\mathrm{Rh}_{2}\left(\mathrm{H}_{2} \mathrm{cit}\right)_{4}$ loaded magnetoliposomes (Lip-Magh- $\mathrm{Rh}_{2}\left(\mathrm{H}_{2} \mathrm{Cit}\right)_{4}$ ) induced a significant decrease, mainly in MCF-7 and 4T1 breast carcinoma cell viability $(\mathrm{p}<0.05)$. This effect was more evident in $4 \mathrm{~T} 1$ cells, which showed a fall in viability of $46 \%( \pm 2.7), 69 \%( \pm 2)$, and $74 \%( \pm 1.4)$ after Magh- $\mathrm{Rh}_{2}\left(\mathrm{H}_{2} \mathrm{Cit}\right)_{4}$ treatment for 24,48 , and $72 \mathrm{~h}$,
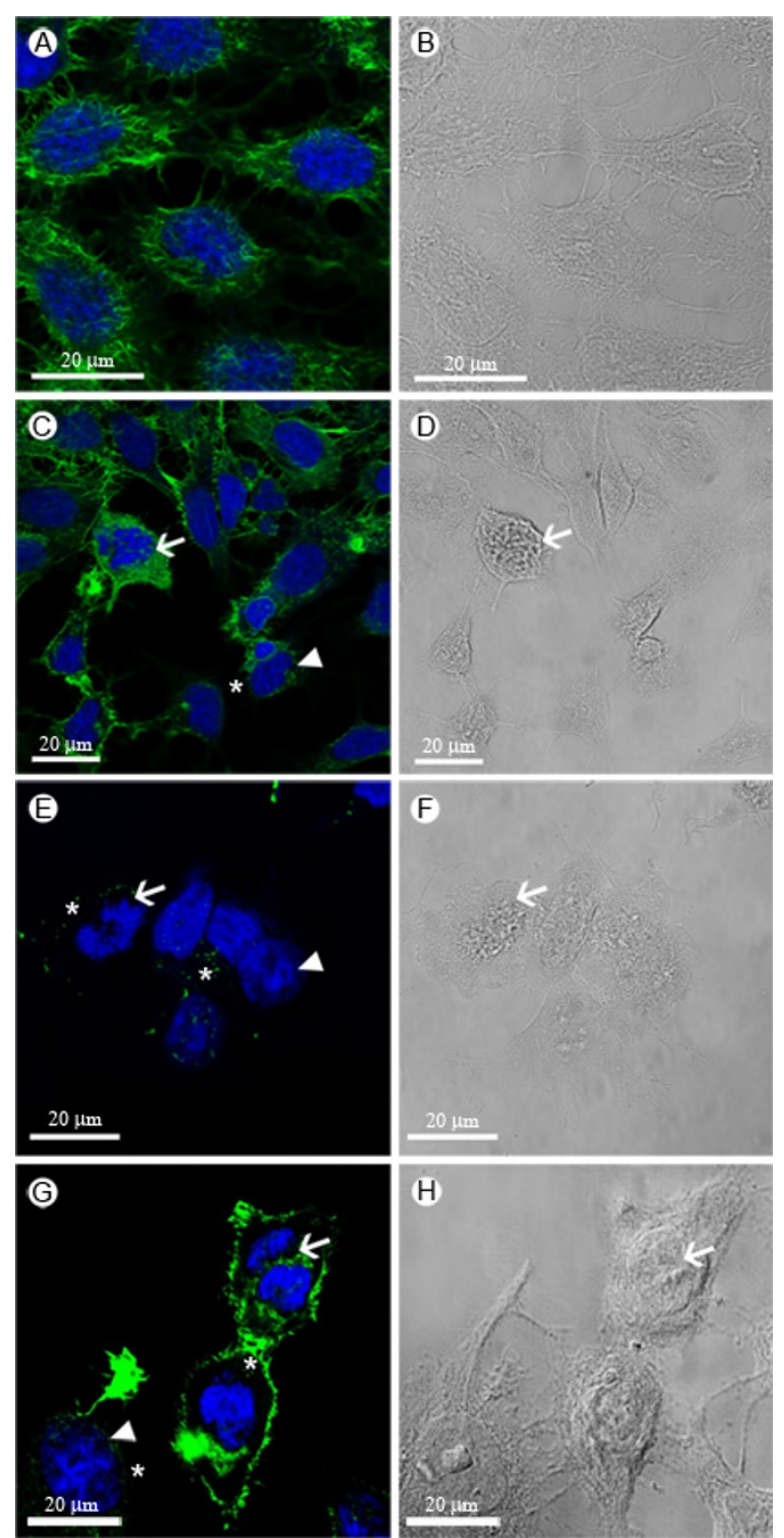

Figure 8 Nuclear fragmentation and reduction of actin filaments in MCF-7 breast carcinoma cells 48 hours after treatment. Cells were stained with DAPI (4',6-diamidino-2-fenilindol) to visualize the nucleus (in blue) and with Phalloidine-Alexa Fluor 488 to visualize actin (in green). (A, B) control (cells without treatment); (C, D) cells treated with $50 \mu \mathrm{M}$ and (E, F) with $500 \mu \mathrm{M}$ of $\mathrm{Rh}_{2}\left(\mathrm{H}_{2} \mathrm{Cit}\right)_{4} ;(\mathrm{G}, \mathrm{H})$ cells treated with $10 \mathrm{nM}$ paclitaxel for $2 \mathrm{~h}$. Arrows and arrow heads indicate nuclear fragmentation and chromatin condensation, respectively. Phase-contrast images are presented for validation of fluorescence (Figure 8B, D, F, H).

respectively. Within the same time frame, the LipMagh- $\mathrm{Rh}_{2}\left(\mathrm{H}_{2} \mathrm{cit}\right)_{4}$ treatment decreased $4 \mathrm{~T} 1$ cell viability by $57 \%( \pm 1.3), 68 \%( \pm 2.4)$, and $84 \%( \pm 2.9)$ after 24,48 and $72 \mathrm{~h}$ treatments, respectively (Figure 9). In contrast, the same dose of free $\mathrm{Rh}_{2}\left(\mathrm{H}_{2} \mathrm{cit}\right)_{4}$ reduced cell viability by about $10 \%( \pm 1.4), 12 \%( \pm 2.6)$, and $18 \%( \pm 2.6)$, after 


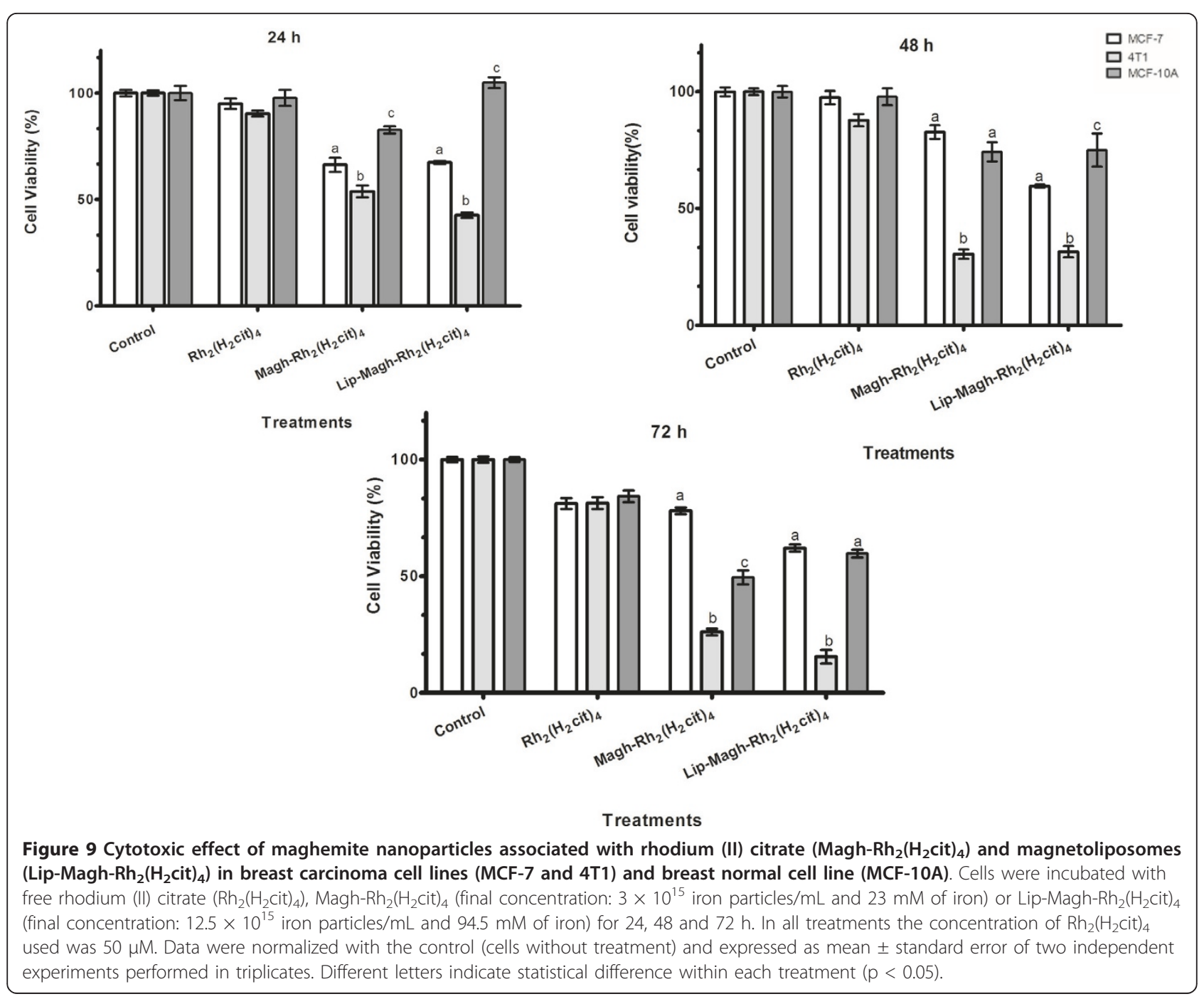

24,48 and $72 \mathrm{~h}$ treatments, respectively $(\mathrm{p}<0.05)$. However, $72 \mathrm{~h}$ of Magh- $\mathrm{Rh}_{2}\left(\mathrm{H}_{2} \mathrm{cit}\right)_{4}$ and Lip-Magh- $\mathrm{Rh}_{2}$ $\left(\mathrm{H}_{2} \mathrm{Cit}\right)_{4}$ treatments on $4 \mathrm{~T} 1$ cells induced a decrease in cell viability of respectively $74 \%( \pm 1.4)$ and $84 \%( \pm 2.9)$ against $18 \%( \pm 2.6)$ presented by the free drug at the same concentration. Thus, Magh- $\mathrm{Rh}_{2}\left(\mathrm{H}_{2} \mathrm{cit}\right)_{4}$ and LipMagh- $\mathrm{Rh}_{2}\left(\mathrm{H}_{2} \mathrm{cit}\right)_{4}$ treatments showed enhanced $\mathrm{Rh}_{2}$ $\left(\mathrm{H}_{2} \mathrm{Cit}\right)_{4}$ potency of up to 3.9 and 4.6 times, respectively.

Longer treatments enhanced the cytotoxicity of both Magh- $\mathrm{Rh}_{2}\left(\mathrm{H}_{2} \mathrm{cit}\right)_{4}$ and Lip-Magh- $\mathrm{Rh}_{2}\left(\mathrm{H}_{2} \mathrm{cit}\right)_{4}$ (Figure 9). After 24 h of treatment with Magh- $\mathrm{Rh}_{2}\left(\mathrm{H}_{2} \mathrm{Cit}\right)_{4}$ and LipMagh- $\mathrm{Rh}_{2}\left(\mathrm{H}_{2} \mathrm{cit}\right)_{4}$, a differential cytotoxicity was observed among the three cell lines. This effect was more pronounced in 4T1 and MCF-7 cells. Further, we observed that Lip-Magh- $\mathrm{Rh}_{2}\left(\mathrm{H}_{2} \mathrm{cit}\right)_{4}$ treatment was more cytotoxic than Magh- $\mathrm{Rh}_{2}\left(\mathrm{H}_{2} \mathrm{cit}\right)_{4}$ to MCF-7 cell line ( $\left.\mathrm{p}<0.05\right)$. A higher cytotoxicity was noticed in MCF-10A $72 \mathrm{~h}$ after the Magh- $\mathrm{Rh}_{2}\left(\mathrm{H}_{2} \mathrm{cit}\right)_{4}$ treatment, but this did not happen with the Lip-Magh- $\mathrm{Rh}_{2}\left(\mathrm{H}_{2} \mathrm{cit}\right)_{4}$ treatment. It is noteworthy that in all time windows and all tested cell lines there was no difference in the viability of the control cells $(\mathrm{p}<0.05)$ (Figure 9).

The cells treated with maghemite nanoparticles without rhodium (II) citrate (Magh) showed no reduction in viability after any treatment duration; however, viability reduction was observed after $72 \mathrm{~h}$ treatment with LipMagh (data not shown).

\section{Discussion}

In this work, the rhodium (II) citrate was isolated from the aqueous solution as powder and not as a single crystal. Due to this fact the complete structure determination cannot be resolved. However, the elemental analysis, ${ }^{13} \mathrm{C}$ NMR, IR, UV/Visible data enable us to predict that the compound structure was similar to the previously studied rhodium (II) carboxylates [23]. In the ${ }^{13} \mathrm{C}$ NMR spectrum (Figure 1B), the signals of $\alpha$ - and $\beta$-carboxyl carbon atoms in the complex appear shifted in comparison with 
those for the free ligand, showing that the citrate anion is coordinated through these two carboxyl groups. In the carbinol carbon atoms, however, only a small shift is observed, indicating that there is no participation of this group in coordination $[24,25]$. Evidence of the coordination of citric acid ligand to rhodium though its carboxyl group was also obtained by infrared spectra, and it was similar to that reported by Najjar and co-workers for rhodium (II) citrate [26]. The coordination by the two different carboxyl groups suggests the formation of five isomeric structures; however, for the development of this work these hypothetic isomers were not separated.

The crystalline structure of magnetic nanoparticles could be confirmed by X-ray difractometry as maghemite phase. According to Magh and Magh- $\mathrm{Rh}_{2}\left(\mathrm{H}_{2} \text { cit }\right)_{4}$ magnetization curves profile (Figure 2B), the nanoparticles present superparamagnetic behavior at room temperature and saturation magnetization close to values already published in the literature for $7 \mathrm{~nm}$ maghemite. The effect of the complex on the particle's surface to saturation magnetization is negligible [27].

Surface functionalization of SPIO with rhodium (II) citrate produced deep changes in the nanoparticles' physical-chemical properties. These changes were evidenced by infrared spectroscopy and zeta potential measurements, as well as by saturation of magnetization. The infrared spectra of Magh- $\mathrm{Rh}_{2}\left(\mathrm{H}_{2} \mathrm{cit}\right)_{4}$ (Figure 2C) showed intense absorptions assigned to asymmetrical $v_{\text {as }}$ $(\mathrm{COO})$ and symmetrical $v_{\mathrm{s}}(\mathrm{COO})$ stretching modes of carboxylate groups [21], indicating the chemical adsorption of $\mathrm{Rh}_{2}\left(\mathrm{H}_{2} \mathrm{cit}\right)_{4}$ molecules into the oxide surface [22]. Zeta potential versus $\mathrm{pH}$ measurements indicated an isoelectric point (iep) at about $\mathrm{pH} 3$. The zeta potential becomes negative in the range of $\mathrm{pH}$ above 3 and its magnitude at $\mathrm{pH} 7$ is about $-38 \mathrm{mV}$. This zeta potential value shows that the particles are negatively charged and indicates an efficient electrostatic stabilization.

It is well known that the magnetic properties of nanomaterials are dependent on their size. Particles smaller than $10 \mathrm{~nm}$, besides having high magnetic applicability, are also ideal to avoid recognition by the mononuclear phagocyte system and, thus, stay longer in the bloodstream [16]. Considering the particle size, Magh- $\mathrm{Rh}_{2}\left(\mathrm{~h}_{2} \mathrm{cit}\right)_{4}$ has potential for applications in the biological system as it presents a modal diameter of $7.5 \mathrm{~nm}$. Moreover, considering the magnetoliposome size, as determined by zetasizer equipment (Figure 3), we could conclude that the small lipid bilayer vesicle will increase the interaction of the active compounds with cells as a normal behavior of other liposomal drug delivery systems (DDS) of similar size carrying similar nanoparticles to the cellular target [28].

In our in vitro study, we observed that cell lines MCF-7, 4T1, and MCF-10A exhibited cytotoxicity when treated with $\mathrm{Rh}_{2}\left(\mathrm{H}_{2} \mathrm{cit}\right)_{4}$. It is reported that others carboxylates such as acetate, butyrate, and propionate of rhodium, in association with isonicotinic acid, also induces cytotoxicity in tumor cells (K562 leukemia cell line) [29]. We also observed that $\mathrm{Rh}_{2}\left(\mathrm{H}_{2} \mathrm{cit}\right)_{4}$ cytotoxicity was dose and time dependent. High concentrations of $\mathrm{Rh}_{2}\left(\mathrm{H}_{2} \mathrm{cit}\right)_{4}$ (up to $200 \mu \mathrm{M}$ ) were seen to induce greater cytotoxicity after longer treatments (72 hours). Furthermore, it was also demonstrated that its cytotoxic effect differed between breast normal (MCF-10A) and breast carcinoma (4T1 and MCF-7) cell lines, being more pronounced in breast normal cells (Table 1 and 2). Our data are, therefore, in agreement with a number of other preliminary studies. For instance, preliminary studies showed that rhodium (II) citrate induces a higher cytotoxicity, with increasing dose and duration of treatment, on breast carcinoma cells (Ehrlich) and on carcinoma (Y-1) and normal adrenocortical cells (AR-1(6)) [7]. Similarly, it was also reported that other rhodium carboxylates such as acetate, methoxyacetate, propionate, and butyrate inhibited the proliferation of leukemia cells (L1210), inducing cytotoxic effects in a dose and a time-dependent manner [30].

Several studies reported promising antitumor activities of rhodium carboxylates in mouse bearing Ehrlich breast carcinoma, but their clinical use has been limited because they showed toxicity in normal cells [4,31]. In our study, $\mathrm{Rh}_{2}\left(\mathrm{H}_{2} \text { cit }\right)_{4}$ was also cytotoxic to in vitro normal cells. The $\mathrm{IC}_{50}$ values (Table 2 ) showed that $\mathrm{Rh}_{2}$ $\left(\mathrm{H}_{2} \mathrm{Cit}\right)_{4}$ cytotoxic effect was more intense on breast normal cells (MCF-10A) than on breast carcinoma cells (MCF-7 and 4T1). However, according to the $\mathrm{IC}_{50}$ values (Table 2), we demonstrated that rhodium (II) citrate is less toxic to normal cells than are members of the lipophilic complex, such as propionate, butyrate, and acetate of rhodium [30]. Therefore, this complex may have a higher chemotherapeutic potential in relation to other carboxylates. The distinctness of cytotoxicity among lipophilicity por hydrophilicity carboxylates could be explained by the differences among their properties, such as chain length and hydrophilicity of parts of the molecules [4].

The cytotoxic activity of some rhodium carboxylates is given by their ability to bind covalently to DNA bases, unpairing them, and subsequently inhibiting DNA replication and transcription [5,7]. It was reported that rhodium carboxylates establish adducts through their axial ligands with electron donor atoms, preferably N, S, O, and $\mathrm{P}$, from molecules such as adenine, cysteine, and RNase A [32]. Moreover, enzymes with free thiol groups $(-\mathrm{SH})$ are known to interact irreversibly with these metal complexes [30]. This interaction could explain the inactivation of some essential DNA replication enzymes which result in their damage. Thus, $\mathrm{Rh}_{2}\left(\mathrm{H}_{2} \mathrm{Cit}\right)_{4}$ is toxic to both normal and carcinoma cells since they need 
DNA replication and transcription to survive. Zyngier and colleagues [7] demonstrated that $\mathrm{Rh}_{2}\left(\mathrm{H}_{2} \mathrm{Cit}\right)_{4}$ inhibited DNA synthesis of breast carcinoma (Ehrlich), and also of carcinoma (Y-1) and, normal adrenocortical cells (AR-1(6)). We observed fragmentation nucleus induced by $\mathrm{Rh}_{2}\left(\mathrm{H}_{2} \mathrm{cit}\right)_{4}$ (Figure $5 \mathrm{D}$ and $6 \mathrm{D}$, Figure $8 \mathrm{C}$ and $8 \mathrm{E}$ ). These observations suggest that $\mathrm{Rh}_{2}\left(\mathrm{H}_{2} \mathrm{cit}\right)_{4}$ not only induces DNA fragmentation on MCF-7 and 4T1 cells, but may also prevent their DNA synthesis.

According to our TEM observations, the MCF-7 and 4T1 cells exhibited condensed mitochondria after $\mathrm{Rh}_{2}$ $\left(\mathrm{H}_{2} \mathrm{cit}\right)_{4}$ treatment (Figure 5D, F and 5F), indicating that this organelle is somehow affected by the complex. This condensed mitochondria phenotype can be associated with a drop in the mitochondrial membrane potential related to the cell death process [33].

We observed that $\mathrm{Rh}_{2}\left(\mathrm{H}_{2} \mathrm{cit}\right)_{4}$ induced an increase in the number of vacuoles compared to the untreated cells, as shown in TEM (Figure 5 and 6). It can indicate a degradation pathway related to the response to metabolic stress or microenvironmental conditions to ensure energy balance. Moreover, this increase has been implicated in the cell death process $[34,35]$.

After $48 \mathrm{~h}$ of treatment with $500 \mu \mathrm{M} \mathrm{Rh}{ }_{2}\left(\mathrm{H}_{2} \mathrm{cit}\right)_{4}$, an increase of annexin- $\mathrm{V}^{+}$breast carcinoma cells was observed (Figure 7). The presence of annexin- $\mathrm{V}^{+}$in cells is related to apoptotic events, since it indicates the exposure of phosphatidylserine outside the inner membrane. The actin analysis performed by confocal microscopy showed a dose-dependent disassembly of the actin cytoskeleton after $\mathrm{Rh}_{2}\left(\mathrm{H}_{2} \mathrm{cit}\right)_{4}$ treatment in the MCF-7 cell (Figure 8). Furthermore, there was a notable reduction in intercellular communication, possibly caused by changes in the actin cytoskeleton (Figure 8). This structure is an important target for many antitumor drugs since it plays a crucial role in maintaining cell morphology, mitosis, signaling regulation for cell survival, and cell motility [36-38]. We demonstrated that the reduction of actin after $\mathrm{Rh}_{2}\left(\mathrm{H}_{2} \mathrm{cit}\right)_{4}$ treatment $(500 \mu \mathrm{M})$ is intrinsically related to the higher cytotoxicity of this complex in MCF-7 cells (Table 1 and Figure 8).

In summary, $\mathrm{Rh}_{2}\left(\mathrm{H}_{2} \mathrm{Cit}\right)_{4}$ induces alterations in the treated cells that are related to the apoptosis process, such as nuclear fragmentation, blebbing, disassembly of the actin cytoskeleton, and phosphatidylserine exposure in the plasma membrane. These features suggest that $\mathrm{Rh}_{2}\left(\mathrm{H}_{2} \mathrm{cit}\right)_{4}$ has potential as an efficient chemotherapic agent since targeting of chemotherapeutic agents is related to its capacity to induce apoptosis.

In order to reduce the toxicity of $\mathrm{Rh}_{2}\left(\mathrm{H}_{2} \mathrm{cit}\right)_{4}$ for normal cells while enhancing the efficacy in carcinoma therapy, we proposed its association with magnetic nanoparticles. Doses of $50 \mu \mathrm{M}$ of $\mathrm{Rh}_{2}\left(\mathrm{H}_{2} \mathrm{cit}\right)_{4}$-loaded to maghemite nanoparticles and to magnetoliposomes were more cytotoxic than the equimolar dose of free $\mathrm{Rh}_{2}$ $\left(\mathrm{H}_{2} \mathrm{cit}\right)_{4}$. Besides, the treatment with $50 \mu \mathrm{M}$ of Magh$\mathrm{Rh}_{2}\left(\mathrm{H}_{2} \mathrm{cit}\right)_{4}$ induced cytotoxicity similar to a tenfold dose of the free complex on carcinoma cells. In addition, the Magh- $\mathrm{Rh}_{2}\left(\mathrm{H}_{2} \mathrm{cit}\right)_{4}$ and Lip-Magh- $\mathrm{Rh}_{2}\left(\mathrm{H}_{2} \mathrm{cit}\right)_{4}$ induced time-dependent cytotoxic effect like those of free $\mathrm{Rh}_{2}\left(\mathrm{H}_{2} \text { cit }\right)_{4}$. After $72 \mathrm{~h}$, for example, Magh- $\mathrm{Rh}_{2}$ $\left(\mathrm{H}_{2} \mathrm{Cit}\right)_{4}$ and Lip-Magh- $\mathrm{Rh}_{2}\left(\mathrm{H}_{2} \mathrm{cit}\right)_{4}$ treatments enhanced cytotoxicity potency up to 3.9 and 4.6 times, respectively. More importantly, MCF-7 and 4T1 carcinoma breast cells were more susceptible to Magh- $\mathrm{Rh}_{2}\left(\mathrm{H}_{2} \mathrm{cit}\right)_{4}$ and Lip-Magh- $\mathrm{Rh}_{2}\left(\mathrm{H}_{2} \mathrm{cit}\right)_{4}$ treatments than MCF-10A normal breast cells, differently from what is observed with free $\mathrm{Rh}_{2}\left(\mathrm{H}_{2} \mathrm{cit}\right)_{4}$ (Table 2 and Figure 9).

Carcinoma and normal cells present different metabolism in relation to iron uptake. The metabolism of breast carcinoma cells, for example, is faster than in normal cells. Consequently, carcinoma cells require larger amounts of micronutrients, particularly iron, which can be evidenced by the presence of more transferrin receptors in these [39]. In this way, an increased iron uptake by tumor cells could result in a selective uptake and a higher retention of Magh- $\mathrm{Rh}_{2}\left(\mathrm{H}_{2} \text { cit }\right)_{4}$ and Lip-Magh- $\mathrm{Rh}_{2}\left(\mathrm{H}_{2} \text { cit }\right)_{4}$ in relation to free $\mathrm{Rh}_{2}\left(\mathrm{H}_{2} \mathrm{Cit}\right)_{4}$ complex. Additionally, magnetic nanoparticle uptake by carcinoma cells may also be associated with the amino group's coverage of nanoparticles [40]. The literature reports that free thiol groups $(-\mathrm{SH})$ interact with the rhodium carboxylates, which are rich in carboxylic groups [30]. Therefore, the carboxylic groups present in Magh- $\mathrm{Rh}_{2}\left(\mathrm{H}_{2} \mathrm{Cit}\right)_{4}$ citrate molecules could improve the transport of nanoparticles through the cell membrane via the proteic thiol groups.

Although rhodium (II) citrate-coated maghemite nanoparticles seem not to have been described before, the association of rhodium complex with polymeric microspheres of hydroxy-propyl-cyclodextrin [41] and with cyclodextrins from hydroxyapatite has been reported [42]. These associations were shown to represent a promising alternative in the minimization of the nonspecific toxicity of these agents, mainly because they increase the efficiency of encapsulation and the duration of rhodium (II) citrate release. Our study demonstrated that the composition of maghemite nanoparticles coated with citrate or rhodium (II) citrate was appropriate for its application as a drug delivery system. Coating with the citrate molecule was able to stabilize our magnetic nanoparticles and also was not toxic to the investigated cells (data not shown). Citrate-functionalized-maghemite has been attested as providing successful nanoparticles in the production of biocompatible and stable magnetic fluids $[43,44]$. Furthermore, citrate-functionalizedmaghemite was also shown to be internalized by in vitro human melanoma cells (SKMEL 37) with no significant cytotoxicity even when cultivated for $72 \mathrm{~h}$ [45]. 
We demonstrated that Magh- $\mathrm{Rh}_{2}\left(\mathrm{H}_{2} \mathrm{cit}\right)_{4}$ and LipMagh- $\mathrm{Rh}_{2}\left(\mathrm{H}_{2} \mathrm{cit}\right)_{4}$ compositions reduced more efficiently the viability of MCF-7 and 4T1 breast carcinoma cells than the free $\mathrm{Rh}_{2}\left(\mathrm{H}_{2} \mathrm{cit}\right)_{4}$ treatment. Furthermore, it is important to emphasize that the cytotoxicity induced by both Magh- $\mathrm{Rh}_{2}\left(\mathrm{H}_{2} \mathrm{Cit}\right)_{4}$ and Lip-Magh- $\mathrm{Rh}_{2}\left(\mathrm{H}_{2} \mathrm{Cit}\right)_{4}$ was greater in tumor cells than normal ones, since no cytotoxicity was observed after treatment with Magh. In addition, if these nanosystems were associated to target molecules for breast carcinoma cells such as folic acid, for instance, their potential for selective uptake would be even higher [46]. Thus, Magh- $\mathrm{Rh}_{2}\left(\mathrm{H}_{2} \mathrm{cit}\right)_{4}$ and LipMagh- $\mathrm{Rh}_{2}\left(\mathrm{H}_{2} \mathrm{cit}\right)_{4}$ have much potential for application in drug delivery systems, and they should be considered as a platform to enhance $\mathrm{Rh}_{2}\left(\mathrm{H}_{2} \mathrm{cit}\right)_{4}$ cytotoxicity, specifically in breast carcinoma.

\section{Conclusions}

We showed that $\mathrm{Rh}_{2}\left(\mathrm{H}_{2} \mathrm{cit}\right)_{4}$ induces significant cytotoxic effects, especially after longer treatments and at higher concentrations. These effects were related to several structural and morphological alterations, probably coming from cell death by apoptosis and autophagy. Further, higher cytotoxicity in the MCF-10A breast normal cell line was noted than in the 4T1 and MCF-7 breast cancer cell lines. Nonetheless, the Magh- $\mathrm{Rh}_{2}$ $\left(\mathrm{H}_{2} \mathrm{Cit}\right)_{4}$ and Lip-Magh- $\mathrm{Rh}_{2}\left(\mathrm{H}_{2} \mathrm{Cit}\right)_{4}$ treatments were more selective to breast cancer cells with up to 4.6 times enhanced potency in comparison to the free $\mathrm{Rh}_{2}$ $\left(\mathrm{H}_{2} \mathrm{Cit}\right)_{4}$. Therefore, we suggest that Magh- $\mathrm{Rh}_{2}\left(\mathrm{H}_{2} \mathrm{Cit}\right)_{4}$ and Lip-Magh- $\mathrm{Rh}_{2}\left(\mathrm{H}_{2} \mathrm{Cit}\right)_{4}$ should be considered a suitable and effective platform for drug delivery systems that operate more specifically in tumor cells.

\section{Methods}

\section{Materials}

All solvents and reagents related to the synthesis of $\mathrm{Rh}_{2}$ $\left(\mathrm{H}_{2} \mathrm{Cit}\right)_{4}$ and Magh- $\mathrm{Rh}_{2}\left(\mathrm{H}_{2} \mathrm{cit}\right)_{4}$ are of analytical grade and were used without further purification: iron(II) chloride tetrahydrate (Acros); iron (III) chloride hexahydrate (Ecibra); hydrated rhodium (III) chloride (SigmaAldrich); citric acid (Vetec), and sodium hydroxide (FMaia). The rhodium(II) trifluoroacetate, $\left[\mathrm{Rh}_{2}(\mathrm{tfa})_{4}\right]$, was prepared following a previously reported procedure [47].

\section{- Characterization of Rhodium Compounds}

Infrared spectra were recorded using $\mathrm{KBr}$ pellets on a Bomem BM100 FT-IR spectrometer in the $4000-500 \mathrm{~cm}^{-1}$ region. Elemental analyses were carried out on a PerkinElmer 2400 analyzer. Rhodium concentrations were measured in Spectro Ciros CCD ICP-AES spectrometer. The samples were digested with concentrated $\mathrm{HCl}$ in an aqueous solution. Electronic spectra were recorded in the
800-200 nm range on Beckman DU70 spectrometer in water solution. The ${ }^{13} \mathrm{C}$ NMR spectra (carbon-13 nuclear magnetic resonance spectroscopy) were obtained at room temperature in $\mathrm{D}_{2} \mathrm{O}$ using a Bruker Avance III 500 spectrometer, operating at a frequency of $125.75 \mathrm{MHz}$. The ${ }^{13} \mathrm{C}$ chemical shifts were measured relative to TMS (tetramethylsilane) measurements. TGA (thermogravimetric analysis) was performed at a heating rate of $10^{\circ} \mathrm{C} \mathrm{min}^{-1}$ in the temperature range of $25-1000^{\circ} \mathrm{C}$, under nitrogen flow of $10 \mathrm{~mL} \mathrm{~min}^{-1}$ using a Shimadzu DTG-60 instrument and standard aluminum crucible. The ESI mass spectra (Electrospray ionisation-mass spectrometry) were acquired using a Bruker Daltonics Esquire 3000 Plus mass spectrometer in capillary exit voltage set at $4 \mathrm{kV}$ and the desolvation chamber temperature was set to $280^{\circ} \mathrm{C}$. Potentiometric titration of an aqueous solution of $\mathrm{Rh}_{2}$ $\left(\mathrm{H}_{2} \mathrm{cit}\right)_{4} 0.0051 \mathrm{molL}^{-1}$ was performed in triplicate using a $0.046 \mathrm{molL}^{-1} \mathrm{NaOH}$ solution as titrant.

\section{- Characterization of Magnetic Nanoparticles}

X-ray powder diffraction (XRD) data were collected by a XRD-6000 diffractometer. The magnetization of the iron oxide nanoparticles was measured at room temperature using a vibrating-sample magnetometer (EV9-VSM AdMagnets). The iron concentration in the fluids was determined by the method of $o$-phenanthroline [48]. Solution absorbances were measured at $512 \mathrm{~nm}$ in a Hitachi U1100. Zeta potential was obtained from electrophoretic mobility (em) measurements performed by phase analysis light scattering using ZetaSizer Nano ZS ZEN3600 (Malvern, UK) equipment. The mean hydrodynamic particle size of Magh- $\mathrm{Rh}_{2}\left(\mathrm{H}_{2} \mathrm{Cit}\right)_{4}$ was determined in water by dynamic laser light scattering (DLS) and the correlation functions were evaluated by cumulant analysis. Maghemite nanoparticles were dispersed in an electrolyte $\left(0.005 \mathrm{molL}^{-1} \mathrm{NaCl}\right)$ solution to get a $0.05 \mathrm{molL}^{-1}$ iron content.

Moreover, to determine the nanoparticles' shape and size by transmission electron microscopy (TEM) an aliquot $(10 \mu \mathrm{L})$ of synthesized (Magh- $\left.\mathrm{Rh}_{2}\left(\mathrm{H}_{2} \mathrm{cit}\right)_{4}\right)(0.2 \%)$ and Lip-Magh- $\mathrm{Rh}_{2}\left(\mathrm{H}_{2} \mathrm{cit}\right)_{4}(0.4 \%)$ was deposited on a copper grid (300 mesh), previously covered with Formvar $(0.7 \%)$, and dried at room temperature. It was then observed under transmission electron microscopy (TEM, JEOL 1011, 100kV) and the images were captured by a Gatan Ultrascan camera. Nanoparticles ( $\mathrm{n}=$ 370) were measured by Image Pro-Plus 5.1 software and data were adjusted by log normal distribution to obtain the modal diameter.

- Synthesis of the Rhodium (II) Citrate Complex, $\mathrm{Rh}_{2}\left(\mathrm{H}_{2} \mathrm{cit}\right)_{4}$ Firstly, an aqueous solution of rhodium (II) trifluoroacetate (c.a. $1 \mathrm{mmol}$ ) was slowly added to a solution of citric acid (c.a.10 mmol) in water under stirring and heated to 
$70^{\circ} \mathrm{C}$. The solvent was reduced almost to dryness followed by addition of water, and this process was repeated four times. The product was dissolved in methanol and precipitated with petroleum ether and acetone 50:50 (v/ v). The solid was washed with ethyl acetate about twenty times to eliminate the excess of ligand.

Yield: 20\%. Anal. Calc for $\left[\mathrm{Rh}_{2}\left(\mathrm{C}_{6} \mathrm{H}_{8} \mathrm{O}_{7}\right)_{4}\left(\mathrm{H}_{2} \mathrm{O}\right)_{2}\right]$ : $\mathrm{C}$, 28.64; H 3.2; Rh, 20.4; $\mathrm{H}_{2} \mathrm{O}, 3.5 \%$. Found: C, 28.5; $\mathrm{H}$, 3.6; Rh, 20.8; $\mathrm{H}_{2} \mathrm{O}, 4.41 \%$. IR (KBr): $v(\mathrm{COOH}) 1724 \mathrm{~s} ; v_{\text {as }}$ $\left(\mathrm{CO}_{2}\right) 1598 \mathrm{vs} ; v_{\mathrm{s}}\left(\mathrm{CO}_{2}\right) 1411 \mathrm{vs} \mathrm{cm}^{-1}$. ESI-MS $(\mathrm{m} / \mathrm{z})$ for $\left[\mathrm{Rh}_{2}\left(\mathrm{C}_{6} \mathrm{H}_{7} \mathrm{O}_{7}\right)_{4}+\mathrm{H}\right]^{+}:$970.8. ${ }^{13} \mathrm{C}$ NMR: $\gamma_{\mathrm{C}}(125.75 \mathrm{MHz}$, $\left.\mathrm{D}_{2} \mathrm{O}\right)$ ppm: $46.3\left(\mathrm{CH}_{2}\right) ; 76.3(\mathrm{C}-\mathrm{OH}) ; 176.4\left(\mathrm{CO}_{2} \mathrm{H}\right)_{\beta}$; $179.8\left(\mathrm{CO}_{2} \mathrm{H}\right)_{\alpha} ; 192.9\left(\mathrm{Rh}-\mathrm{CO}_{2}\right)_{\beta} ; 195.3\left(\mathrm{Rh}-\mathrm{CO}_{2}\right)_{\alpha}$. UVvis $\left(\mathrm{H}_{2} \mathrm{O}, \mathrm{nm}\right): 586\left(\pi^{*}{ }_{(\mathrm{RhRh})} \rightarrow \sigma^{*}{ }_{(\mathrm{RhRh})}\right) ; 442\left(\pi^{*}{ }_{(\mathrm{RhRh})}\right.$ $\left.\rightarrow \sigma^{*}{ }_{(\mathrm{RhO})}\right)$; $292\left(\sigma_{(\mathrm{RhO})} \rightarrow \sigma^{*}{ }_{(\mathrm{RhRh})}\right)$.

\section{- Preparation of maghemite nanoparticles functionalized with Rhodium Compound, Magh- $\mathrm{Rh}_{\mathbf{2}}\left(\mathrm{H}_{2} \mathrm{Cit}\right)_{4}$}

Maghemite $\left(\gamma-\mathrm{Fe}_{2} \mathrm{O}_{3}\right)$ nanoparticles were prepared according to procedures described previously [49]. Magnetite $\left(\mathrm{Fe}_{3} \mathrm{O}_{4}\right)$ nanoparticles were synthesized by mixing $\mathrm{FeCl}_{2}$ and $\mathrm{FeCl}_{3}$ aqueous solutions (2:1 molar ratio) with $\mathrm{NaOH}$ solution under vigorous stirring. The solid was washed with distilled water until $\mathrm{pH}=9$ and oxidation of magnetite to maghemite was performed adjusting the $\mathrm{pH}$ to 3 , stirring the dispersion under heating and constant oxygen flow. The reddish sediment was centrifuged, dispersed in water, and dialyzed for 24 hours.

In the second stage of the nanocomposite preparation procedure, the magnetic nanoparticles were functionalized with rhodium (II) citrate. For this purpose, $5 \mathrm{~mL}$ of the magnetic dispersion and $1 \mathrm{~mL}$ of rhodium (II) citrate solution $\left(0.054 \mathrm{molL}^{-1}\right)$ were mixed and stirred for two hours at room temperature. The nanoparticles were separated by centrifugation (5000 rpm), washed three times with deionized water and thereafter dispersed in $5 \mathrm{~mL}$ of water. The stable magnetic solution containing Magh- $\mathrm{Rh}_{2}\left(\mathrm{H}_{2} \mathrm{Cit}\right)_{4}$ nanoparticles was obtained by adjusting the $\mathrm{pH}$ to 7 .

\section{- Preparation and characterization of Magnetoliposomes} A small unilamellar liposome based on L- $\alpha$-phosphatidylcholine and L- $\alpha$-lysophosphatidylcholine was made according to the modified injection method described elsewhere [28]. We used L- $\alpha$-lysophosphatidylcholine because the formed vesicles are smaller and this leads to an increase in the permeability of the liposomal formulation through the cells [50]. Basically, $360 \mu \mathrm{L}$ of an ethanolic solution containing $0.686 \mathrm{mM}$ L- $\alpha$-phosphatidylcholine, $0.0137 \mathrm{mM}$ L- $\alpha$-lysophosphatidylcholine, was injected with a syringe into $5 \mathrm{~mL}$ phosphate buffer solution (PBS), $\mathrm{pH}$ 7.4. The injection of $262 \mu \mathrm{L}$ of maghemite nanoparticles with rhodium (II) citrate into PBS was performed at $56^{\circ} \mathrm{C}$, under magnetic stirring at a flow rate $1 \mu \mathrm{L} / \mathrm{s}$ to a final concentration of $1.96 \times 10^{15}$ particle $/ \mathrm{mL}$.

Particle size and size distribution were obtained by laser light scattering using a particle size analyzer (Zetasizer, Malvern, UK). The magnetoliposome suspension containing the maghemite nanoparticles (Magh- $\mathrm{Rh}_{2}$ $\left.\left(\mathrm{H}_{2} \mathrm{cit}\right)_{4}\right)$ was analyzed in a $1.0 \mathrm{~cm}$ quartz cell. The measurement was performed in triplicates $(n=3)$. All experiments were carried out at $25^{\circ} \mathrm{C}$ in the range of 100-2000 Hz.

\section{- Cell culture}

MCF-7 human mammary carcinoma cell line (purchased from American Type Collection, ATCC, USA) and 4T1 murine mammary carcinoma cells (provided by Dr. Suzanne Ostrand-Rosenberg, Maryland, USA) were cultured in flasks (TPP, Switzerland) with Dulbecco's Modified Eagle's Medium (DMEM-Sigma, USA) containing $1 \%(\mathrm{v} / \mathrm{v})$ penicillin-streptomycin (Sigma) and 10\% (v/v) heat-inactivated fetal bovine serum (FBS-Gibco). Human normal breast cell line MCF-10A (donated by Dr. Maria Mitzi Brentani, USP, Brazil) was cultured with a 1:1 mixture of DMEM and F12 medium (Sigma) supplemented with $5 \%$ horse serum (Gibco), hydrocortisone (0.5 $\mu \mathrm{g} / \mathrm{mL}$, Sigma), insulin ( $1 \mathrm{mg} / \mathrm{mL}$, Sigma), epidermal growth factor $(20 \mathrm{ng} / \mathrm{mL}$, Sigma), choleric toxin (100 ng/mL, Sigma) and 1\% (v/v) penicillin-streptomycin. Cells were maintained at $37^{\circ} \mathrm{C}$ in humidified atmosphere with $5 \% \mathrm{CO}_{2}$.

\section{- Cell treatment}

Cells were seeded into 6 or 96 well culture microplates at a density of $1.4 \times 10^{4}$ cells $/ \mathrm{cm}^{2}$ and incubated for $24 \mathrm{~h}$ to allow cell's adhesion. Then cells were incubated with free $\mathrm{Rh}_{2}\left(\mathrm{H}_{2} \mathrm{cit}\right)_{4}$ (50-600 $\left.\mu \mathrm{M}\right)$, Magh- $\mathrm{Rh}_{2}\left(\mathrm{H}_{2} \mathrm{cit}\right)_{4}$, and Lip-Magh- $\mathrm{Rh}_{2}\left(\mathrm{H}_{2} \mathrm{Cit}\right)_{4}\left(50 \mu \mathrm{M}\right.$ of $\left.\mathrm{Rh}_{2}\left(\mathrm{H}_{2} \mathrm{cit}\right)_{4}\right)$ for 24, 48, and $72 \mathrm{~h}$. As negative control, cells were incubated with maghemite nanoparticles and magnetoliposomes without $\mathrm{Rh}_{2}\left(\mathrm{H}_{2} \text { cit }\right)_{4}$ at the same equimolar iron concentrations found in Magh- $\mathrm{Rh}_{2}\left(\mathrm{H}_{2} \text { cit }\right)_{4}(23 \mathrm{mM}, 3 \times$ $10^{15}$ iron particles/mL) and Lip-Magh- $\mathrm{Rh}_{2}\left(\mathrm{H}_{2} \mathrm{cit}\right)_{4}(94.5$ $\mathrm{mM}, 12.5 \times 10^{15}$ iron particles $\left./ \mathrm{mL}\right)$, respectively. Untreated cells correspond to the control group, while cells treated with paclitaxel, a chemotherapy widely used in clinics, represent the positive control used to validate the model cells. An equimolar dose of $\mathrm{Rh}_{2}\left(\mathrm{H}_{2} \mathrm{Cit}\right)_{4}$ was used in the treatment of cells with paclitaxel (50 micromolar) to compare their cytotoxicity. Dimethyl sulfoxide (DMSO) was used as the paclitaxel treatment control.

\section{- Cell viability assay}

Cell viability was estimated by MTT (Invitrogen, USA) assay. After treatment, as described above, cells were incubated with $15 \mu \mathrm{L}$ of MTT $(5 \mathrm{mg} / \mathrm{mL})$ and $185 \mu \mathrm{L}$ of 
culture medium for two and half hours at $37^{\circ} \mathrm{C}$ in humidified atmosphere with $5 \% \mathrm{CO}_{2}$. Then the culture solution was removed and $200 \mu \mathrm{L}$ of DMSO was added. The absorbance readings were performed by spectrophotometer (SpectraMax M2, Molecular Devices) using a microplate reader at a $595 \mathrm{~nm}$ wavelength. The relative cell viability (\%) was calculated by the formula: $[\mathrm{A}]$ treatment/[A]control $\times 100$, where $[\mathrm{A}]$ treatment is the absorbance of the tested sample and $[\mathrm{A}]$ control is the absorbance of control sample (containing only culture medium).

\section{- Cell morphology and ultra-structural analysis}

The morphology and ultra-structural analysis were carried out after $48 \mathrm{~h}$ of treatment with free $\mathrm{Rh}_{2}\left(\mathrm{H}_{2} \mathrm{Cit}\right)_{4}$ (50 and $500 \mu \mathrm{M})$. Cell morphology was visualized by AxioSkop light microscope (Zeiss, Germany) and images were captured using AxioVision (Zeiss) software. For ultra-structural analysis, cells were washed with PBS and fixed for 1 $\mathrm{h}$ in solution containing $2 \%$ glutaraldehyde $(\mathrm{v} / \mathrm{v}), 2 \%(\mathrm{w} / \mathrm{v})$ paraformaldeyde, and 3\% (w/v) sucrose in $0.1 \mathrm{M}$ sodium cacodylate buffer $\mathrm{pH}$ 7.2. Afterward, cells were rinsed in the same buffer and post fixed, for 40 minutes, in 1\% osmium tetroxide $(\mathrm{w} / \mathrm{v})$ and $0.8 \%$ potassium ferricyanide (10 $\mathrm{mM} \mathrm{CaCl}_{2}$ in $0.2 \mathrm{M}$ sodium cacodylate buffer). The material was washed in distilled water and the block stained was performed for $12 \mathrm{~h}$ with $0.5 \%$ uranyl acetate at $4^{\circ} \mathrm{C}$. Then samples were dehydrated in a graded acetone series $(50-100 \%)$ for 10 minutes each and embedded in Spurr resin. Ultrathin sections were observed in a Jeol ${ }^{\mathbb{R}}$ 1011 transmission electron microscope (MET) at $80 \mathrm{kV}$.

\section{- Annexin-V/propidium iodide staining analysis}

After treatments with 50 and $500 \mu \mathrm{M}$ of free $\mathrm{Rh}_{2}\left(\mathrm{H}_{2} \mathrm{cit}\right)$ 4 , cells $\left(1 \times 10^{6}\right.$ cels $\left./ \mathrm{mL}\right)$ were washed with PBS and resuspended in the solution containing $100 \mu \mathrm{L}$ of binding buffer (10 mM of HEPES/NaOH (pH 7.4), $140 \mathrm{mM}$ $\mathrm{NaCl}, 2.5 \mathrm{mM} \mathrm{CaCl}_{2}$ ), $5 \mu \mathrm{L}$ of anexina-V-FITC (Biosource, USA) and propidium iodide $(5 \mu \mathrm{g} / \mathrm{mL}$, Invitrogen). In this step, cells were incubated for 15 minutes in the dark at room temperature. Next, $400 \mu \mathrm{L}$ of binding buffer were added to the cells and 10,000 events for each sample were acquired by flow cytometry (Becton \& Dickenson, San Jose, CA-USA). After acquisition, the analysis was done by software Cell QuestTM. Cells without staining with annexin and propidium iodide (PI) were used as negative control of fluorescence.

\section{- Actin filaments and nucleus staining analysis}

Firstly, poly-L-lysine (1\%) was added to coverslips placed in six well culture microplates and incubated overnight at $4^{\circ} \mathrm{C}$. Cells were then attached to coverslips and, after $48 \mathrm{~h}$ of treatments with free $\mathrm{Rh}_{2}\left(\mathrm{H}_{2} \mathrm{cit}\right)_{4}$ (50 and 500 $\mu \mathrm{M})$, they were washed with PBS and fixed with $3.5 \%$ paraformaldehyde for ten minutes at room temperature (RT). Next, the cells were permeabilized with $0.1 \%$ Triton-PBS for three minutes, washed with PBS, and incubated with $1 \%$ bovine serum albumin (BSA) for 30 minutes. Subsequently, the cells were stained with solution containing 2.5\% Phaloidin-Alexa-Fluor 488 and $1 \%$ BSA (v/v) for 20 minutes and, after this time, $1 \mu \mathrm{g} /$ $\mathrm{mL}$ of DAPI (4',6-diamidino-2-fenilindol) was added to cells for seven minutes in the dark at RT. The cells were washed twice with water, five minutes each, and then the coverslips were placed in slides with $4 \% \mathrm{~N}$-propil galate. Afterwards, the cells were examined and images were captured by laser scanning confocal microscopy (Leica SP5). All microscopy gain and offset settings were maintained constant throughout the study.

\section{- Statistical Analysis}

To determine the difference in the cell line's viability and in the annexin- $\mathrm{V} /$ propidium iodide staining among treatment groups over treatment time and cell line, an analysis of variance (ANOVA) with general linear model procedure followed by post hoc Tukey or Dunnet's test was used. Data were presented as mean value \pm SEM of at least two independent experiments (SPSS, Inc., Chicago, IL, version 17.0). The $\mathrm{IC}_{50}$ or $\mathrm{EC}_{50}$ values and their 95\% confidence intervals (CI 95\%) were obtained by nonlinear regression (Sigma Stat; Prism 5.0; GraphPad Software Inc., San Diego, CA). The significance level was set at $\mathrm{p}<0.05$. In order to characterize the nanoparticles' size and morphology, the experimental data were fitted to a curve using a log-normal distribution function, and the modal diameter was obtained (SPSS, Inc., Chicago, IL, version 17.0).

\section{Acknowledgements}

This research was supported by the "Conselho Nacional de Desenvolvimento Científico e Tecnológico" (CNPQ), "Coordenação de Aperfeiçoamento de Pessoal de Nível Superior" (CAPES), "Fundação de Apoio a Pesquisa no Distrito Federal" (FAP-DF, Grant: 193.000.466/08) and "Financiadora de Estudos e Projetos" (Finep). The authors are grateful to Prof. Ricardo Bentes de Azevedo for his laboratory support and to Prof. Antônio Raimundo Lima Cruz Teixeira for supplying the flow cytometry equipment. We also thank Ms. Graziella Anselmo Joanitti for her important technical support on flow cytometry proceedings and Calliandra Maria de Souza Silva for her English revision.

\section{Author details}

${ }^{1}$ Instituto de Ciências Biológicas, Universidade de Brasília (UnB), Brazil. 70.919970. ${ }^{2}$ Instituto de Química, Universidade Federal de Goiás (UFG), Brazil.74.001-970. ²Departamento de Química, Laboratório de Fotobiologia e Fotomedicina, Faculdade de Filosofia, Ciências e Letras de Ribeirão Preto, Universidade de São Paulo, 14040-901, Ribeirão Preto-SP, Brazil.

\section{Authors' contributions}

MLBC was the principal investigator and takes primary responsibility for the paper. MLBC, ZGML, ARS* and SNB participated in the design of the study and SNB co-ordinated the research; MLBC, ESN, RCAP, RGSO and LHML performed the laboratory work for this study; ESN and ARS* synthesized the rhodium (II) citrate and rhodium (II) citrate-loaded nanoparticles; ARS\# and 
ACT encapsulated the rhodium (II) citrate-loaded nanoparticles in liposomes, ICRS was responsible for statistical analysis; MLBC, ESN, ARS* and ARS" wrote the manuscript and all authors read and approved the final manuscript.

* Aparecido R de Souza

\# Andreza R Simioni

\section{Competing interests}

We also report that the University of Brasilia has submitted a patent application (in the Brazilian Patent Office - intellectual property number: 012110000013) to license the technology involved. The authors disclose no other potential conflicts of interest.

Received: 16 December 2010 Accepted: 28 March 2011

Published: 28 March 2011

\section{References}

1. Coughlin SS, Ekwueme DU: Breast cancer as a global health concern. Cancer Epidemiol 2009, 33:315-318.

2. Kostova I: Platinum complexes as anticancer agents. Recent Pat Anticancer Drug Discov 2006, 1:1-22.

3. Zhang CX, Lippard SJ: New metal complexes as potential therapeutics. Curr Opin Chem Biol 2003, 7:481-489.

4. Katsaros N, Anagnostopoulou A: Rhodium and its compounds as potential agents in cancer treatment. Crit Rev Oncol Hematol 2002, 42:297-308.

5. Junicke H, Hart JR, Kisko J, Glebov O, Kirsch IR, Barton JK: A rhodium (III) complex for high-affinity DNA base-pair mismatch recognition. Proc Natl Acad Sci USA 2003, 100:3737-3742.

6. Angeles-Boza AM, Chifotides HT, Aguirre JD, Chouai A, Fu PK, Dunbar KR, Turro C: Dirhodium(II, II) complexes: molecular characteristics that affect in vitro activity. J Med Chem 2006, 49:6841-6847.

7. Zyngier S, Kimura E, Najjar R: Antitumor effects of rhodium (II) citrate in mice bearing Ehrlich tumors. Braz J Med Biol Res 1989, 22:397-401.

8. Gupta AK, Gupta M: Synthesis and surface engineering of iron oxide nanoparticles for biomedical applications. Biomaterials 2005, 26:3995-4021.

9. Namdeo M, Saxena S, Tankhiwale R, Bajpai M, Mohan YM, Bajpai SK: Magnetic nanoparticles for drug delivery applications. J Nanosci Nanotechnol 2008, 8:3247-3271.

10. Maeda H, Wu J, Sawa T, Matsumura Y, Hori K: Tumor vascular permeability and the EPR effect in macromolecular therapeutics: a review. J Control Release 2000, 65:271-284.

11. Asadishad B, Vossoughi M, Alamzadeh I: In vitro release behavior and cytotoxicity of doxorubicin-loaded gold nanoparticles in cancerous cells. Biotechnol Lett 2010, 32:649-654.

12. Kohler N, Sun C, Wang J, Zhang M: Methotrexate-modified superparamagnetic nanoparticles and their intracellular uptake into human cancer cells. Langmuir 2005, 21:8858-8864

13. Dreaden EC, Mwakwari SC, Sodji QH, Oyelere AK, El-Sayed MA: Tamoxifenpoly(ethylene glycol)-thiol gold nanoparticle conjugates: enhanced potency and selective delivery for breast cancer treatment. Bioconjug Chem 2009, 20:2247-2253.

14. Ma G, Yang J, Zhang L, Song C: Effective antitumor activity of paclitaxelloaded poly (varepsilon-caprolactone)/pluronic F68 nanoparticles after intratumoral delivery into the murine breast cancer model. Anticancer Drugs 21:261-269.

15. Kettering $M$, Zorn $H$, Bremer-Streck S, Oehring H, Zeisberger M, Bergemann C, Hergt R, Halbhuber K, Kaiser WA, Hilger I: Characterization of iron oxide nanoparticles adsorbed with cisplatin for biomedical applications. Phys Med Biol 2009, 54:5109-5121.

16. Douziech-Eyrolles L, Marchais H, Herve K, Munnier E, Souce M, Linassier C, Dubois $P$, Chourpa I: Nanovectors for anticancer agents based on superparamagnetic iron oxide nanoparticles. Int J Nanomedicine 2007, 2:541-550

17. Sun YK, Ma M, Zhang Y, Gu N: Synthesis of nanometer-size maghemita particles from magnetite. Colloids and Surfaces A: Physicochemical and Engineering Aspects 2004, 245:15-19.

18. International Center of Diffraction Data. PDF Card 22-1086 2000

19. Batlle $X$, Labarta A: Finite-size effects in fine particles: magnetic and transport properties. Journal of Physics D: Applied Physics 2002, 35:.,15-42.
20. Lu AH, Salabas EL, Schuth F: Magnetic nanoparticles: synthesis, protection, functionalization, and application. Angewandte Chemie 2007, 46:1222-1244.

21. Bellamy L: The Infrared Spectra of Complex Molecules. Chapman and Halli, 31975.

22. Drmota A, Kosak A, Znidarsic A: A mechanism for the adsorption of carboxylic acids onto the surface of magnetic nanoparticles. Materials and Technology 2008, 42:79-83.

23. Boyar EB, Robinson SD: Rhodium(II) Carboxylates. Coordination Chemistry Reviews 1983, 50:109-208.

24. Deng $Y F$, Jiang $Y Q$, Hong QM, Zhou ZH: Speciation of water-soluble titanium citrate: Synthesis, structural, spectroscopic properties and biological relevance. Polyhedron 2007, 26:1561-1569.

25. Zhou ZH, Hou SY, Cao ZX, Tsai KR, Chow YL: Syntheses, spectroscopies and structures of molybdenum(VI) complexes with homocitrate. Inorganic Chemistry 2006, 45:8447-8451.

26. Najjar R, Santos FS, Seidel W: Synthesis and characterization of the rhodium(II) citrate complex. Anais da Academia Brasileira de Ciências 1987, 59:1-2.

27. Liu ZL, Wang HB, Lu QH, Du GH, Peng L, Du YQ, Zhang SM, Yao KL: Synthesis and characterization of ultrafine well-dispersed magnetic nanoparticles. Journal of Magnetism and Magnetic Materials 2004, 283:248-262.

28. Simioni AR, Pelisson MM, Beltrame M, Tedesco AC: Photophysical and photobiological studies of a silicon tribenzonaphthoporphyrazinato incorporated into liposomes for photodynamic therapy use. J Nanosci Nanotechnol 2008, 8:3208-3215.

29. de Souza AR, Najjar R, Glikmanas S, Zyngier SB: Water-soluble rhodium(II) carboxylate adducts: cytotoxicity of the new compounds. J Inorg Biochem 1996, 64:1-5

30. Howard RA, Kimball AP, Bear JL: Mechanism of action of tetra-mucarboxylatodirhodium(II) in L1210 tumor suspension culture. Cancer Res 1979, 39:2568-2573.

31. de Souza AR, Coelho EP, Zyngier SB: Comparison of the anti-neoplastic effects of dirhodium(II) tetrapropionate and its adducts with nicotinate and isonicotinate anions in mice bearing Ehrlich tumors. Eur J Med Chem 2006, 41:1214-1216.

32. Chifotides HT, Dunbar KR: Interactions of metal-metal-bonded antitumor active complexes with DNA fragments and DNA. Acc Chem Res 2005, 38:146-156.

33. Gottlieb E, Armour SM, Harris MH, Thompson CB: Mitochondrial membrane potential regulates matrix configuration and cytochrome $C$ release during apoptosis. Cell Death Differ 2003, 10:709-717.

34. Mizushima N: Methods for monitoring autophagy. Int I Biochem Cell Biol 2004, 36:2491-2502.

35. Turcotte S, Giaccia AJ: Targeting cancer cells through autophagy for anticancer therapy. Curr Opin Cell Biol 22:246-251.

36. Alberti C: Cytoskeleton structure and dynamic behaviour: quick excursus from basic molecular mechanisms to some implications in cancer chemotherapy. Eur Rev Med Pharmacol Sci 2009, 13:13-21.

37. Rosenblum MD, Shivers RR: 'Rings' of F-actin form around the nucleus in cultured human MCF7 adenocarcinoma cells upon exposure to both taxol and taxotere. Comp Biochem Physiol C Toxicol Pharmacol 2000, 125:121-131.

38. Jordan MA, Wilson L: Microtubules and actin filaments: dynamic targets for cancer chemotherapy. Curr Opin Cell Biol 1998, 10:123-130.

39. Kwok JC, Richardson DR: The iron metabolism of neoplastic cells: alterations that facilitate proliferation? Crit Rev Oncol Hematol 2002, 42:65-78.

40. Petri-Fink A, Chastellain M, Juillerat-Jeanneret L, Ferrari A, Hofmann H: Development of functionalized superparamagnetic iron oxide nanoparticles for interaction with human cancer cells. Biomaterials 2005 26:2685-2694.

41. Sinisterra RD, Shastri VP, Najjar R, Langer R: Encapsulation and release of rhodium(II) citrate and its association complex with hydroxypropyl-betacyclodextrin from biodegradable polymer microspheres. J Pharm Sci 1999, 88:574-576.

42. Burgos AE, Belchior JC, Sinisterra RD: Controlled release of rhodium (II) carboxylates and their association complexes with cyclodextrins from hydroxyapatite matrix. Biomaterials 2002, 23:2519-2526. 
43. Lacava ZGM, Azevedo RB, Martins EV, Lavava LM, Freitas MLL, Garcia VAP: Biological effect of magnetic fluids: toxicity studies. Journal of magnetism and magnetic materials 1999, 201:431-434.

44. Morais PC, Santos RL, Pimenta ACM, B AR, D LEC: Preparation and characterization of ultra-stable biocompatible magnetic fluids using citrate-coated cobalt ferrite nanoparticles. Thin solid films 2006, 515:266-270.

45. de Freitas ER, Soares PR, Santos Rde P, dos Santos RL, da Silva JR, Porfirio EP, Bao SN, Lima EC, Morais PC, Guillo LA: In vitro biological activities of anionic gamma- $\mathrm{Fe}_{2} \mathrm{O}_{3}$ nanoparticles on human melanoma cells. J Nanosci Nanotechnol 2008, 8:2385-2391.

46. Sahu SK, Mallick SK, Santra S, Maiti TK, Ghosh SK, Pramanik P: In vitro evaluation of folic acid modified carboxymethyl chitosan nanoparticles loaded with doxorubicin for targeted delivery. J Mater Sci Mater Med 2010, 5:1587-97.

47. Bear JL, Gray HB, Rainen L, Chang IM, Howard R, Serio G, Kimball AP: Interaction of Rhodium(II) carboxylates with molecules of biologic importance. Cancer Chemother Rep 1975, 59:611-620.

48. Jeffery GH, Basset J, Mendham J, Denney RC: VOGEL's Textbook of quantitative chemical analysis. New York: Longman Scientific \& Technicali 51989.

49. Kang YS, Risbud S, Rabolt JF, Stroeve P: Synthesis and characterizations of nanometer-size $\mathrm{Fe}_{3} \mathrm{O}_{4}$ and $\mathrm{g}-\mathrm{Fe}_{2} \mathrm{O}_{3}$ particles. Chemistry of Materials 1996, 8:2209-2211.

50. Ralston E, Blumenthal R, Weinstein JN, Sharrow SO, Henkart P: Lysophosphatidylcholine in liposomal membranes. Enhanced permeability but little effect on transfer of a water-soluble fluorescent marker into human lymphocytes. Biochimica et Biophysica Acta (BBA) Biomembranes 1980, 597:543-551.

doi:10.1186/1477-3155-9-11

Cite this article as: Carneiro et al:: Free Rhodium (II) citrate and rhodium (II) citrate magnetic carriers as potential strategies for breast cancer therapy. Journal of Nanobiotechnology 2011 9:11.

\section{Submit your next manuscript to BioMed Central and take full advantage of:}

- Convenient online submission

- Thorough peer review

- No space constraints or color figure charges

- Immediate publication on acceptance

- Inclusion in PubMed, CAS, Scopus and Google Scholar

- Research which is freely available for redistribution

Submit your manuscript at www.biomedcentral.com/submit 